\title{
Carbon stocks and factors affecting their storage in dry Afromontane forests of Awi Zone, northwestern Ethiopia
}

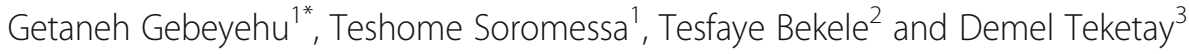

\begin{abstract}
Background: Tropical montane forests played an important role in the provision of ecosystem services. The intense degradation and deforestation for the need of agricultural land expansion result in a significant decline of forest cover. However, the expansion of agricultural land did not completely destruct natural forests. There remain forests inaccessible for agricultural and grazing purpose. Studies on these forests remained scant, motivating to investigate biomass and soil carbon stocks. Data of biomass and soils were collected in 80 quadrats ( $\left.400 \mathrm{~m}^{2}\right)$ systematically in 5 forests. Biomass and disturbance gradients were determined using allometric equation and disturbance index, respectively. The regression modeling is employed to explore the spatial distribution of carbon stock along disturbance and environmental gradients. Correlation analysis is also employed to identify the relation between site factors and carbon stocks.

Results: The result revealed that a total of 1655 individuals with a diameter of $\geq 5 \mathrm{~cm}$, representing 38 species, were measured in 5 forests. The mean aboveground biomass carbon stocks (AGB CS) and soil organic carbon (SOC) stocks at 5 forests were $191.6 \pm 19.7$ and $149.32 \pm 6.8 \mathrm{MgC} \mathrm{ha}^{-1}$, respectively. The AGB CS exhibited significant $(P<0.05)$ positive correlation with SOC and total nitrogen (TN) stocks, reflecting that biomass seems to be a general predictor of SOCs. AGB CS between highly and least-disturbed forests was significantly different $(P<0.05)$. This disturbance level equates to a decrease in AGB CS of $36.8 \%$ in the highly disturbed compared with the least-disturbed forest. In all forests, dominant species sequestrated more than 58\% of carbon. The AGB CS in response to elevation and disturbance index and SOC stocks in response to soil pH attained unimodal pattern. The stand structures, such as canopy cover and basal area, had significant positive relation with AGB CS.

Conclusions: Study results confirmed that carbon stocks of studied forests were comparable to carbon stocks of protected forests. The biotic, edaphic, topographic, and disturbance factors played a significant variation in carbon stocks of forests. Further study should be conducted to quantify carbon stocks of herbaceous, litter, and soil microbes to account the role of the whole forest ecosystem.
\end{abstract}

Keywords: Biomass carbon stock, Disturbances, Dry Afromontane forests, Environmental factors, Regression model, Soil carbon stock

\section{Background}

Tropical forests play an important role in the global carbon $(\mathrm{C})$ cycle and sequestering carbon dioxide to mitigate climate change. They are major sinks for atmospheric carbon, accounting for $50 \%$ of the aboveground carbon in the vegetation (Hunter et al. 2013). Tropical montane forests cover $8 \%$ of the total tropical

\footnotetext{
* Correspondence: getanehgebeyehu@yahoo.com

${ }^{1}$ Center for Environmental Science, Addis Ababa University, Addis Ababa, Ethiopia

Full list of author information is available at the end of the article
}

forest areas (Spracklen and Righelato 2014). They play an important role in the biodiversity conservation and provision of ecosystem services (Spracklen and Righelato 2014). Forests create opportunities for the mitigation of climate change. They stored a considerable amount of carbon stocks if appropriate conservation and management systems existed in the forest sector. The current carbon stock in the world's forests is estimated to be $861 \mathrm{Gt}$ of carbon of which 363 and $383 \mathrm{Gt}$ of carbon are stored in the living biomass and soil (up to $1 \mathrm{~m}$ ), respectively (Pan et al. 2011). As a region of tropical

(c) The Author(s). 2019 Open Access This article is distributed under the terms of the Creative Commons Attribution 4.0 International License (http://creativecommons.org/licenses/by/4.0/), which permits unrestricted use, distribution, and 
forest, a larger amount of carbon is stored in aboveground biomass (56\%) compared to the soil (32\%) (Pan et al. 2011). This figure indicates that biomass and soils have a large potential for temporary and long-term carbon storage (Houghton 2005). However, carbon storage in global forests varies greatly in both its magnitude and within-system distribution, depending on conservation and management (Chen et al. 2014).

Forests also create a threat and can release $\mathrm{CO}_{2}$ to the atmosphere in places where deforestation and forest degradation continue. Thus, forest carbon can be a threat in the global $\mathrm{C}$ cycle depending on the management systems. Deforestation has altered the concentration of greenhouse gases in the atmosphere, thereby affecting climate and biodiversity, and become a threat by changing the global C cycle (Harris et al. 2012). In contrast, the reduction of the rates of deforestation and forest degradation (REDD) as well as promote sustainable forest management (REDD +) activities, which are targeted to enhance carbon (C) sequestration and maintain in situ $\mathrm{C}$ stocks, underlines the importance of mitigating the effects of climate change (UNFCCC 2010; Goetz et al. 2015).

Diverse climatic conditions and topographic and edaphic variations allow the occurrence of a wide range of forest vegetation in Ethiopia (Teketay et al. 2010). An early study of the flora of Ethiopia in the country revealed the existence of about 6027 vascular plant species (Kelbessa and Demissew 2014). Plants support and maintain ecosystem functioning, thereby contributing towards alleviating the effects of climate change by sequestering atmospheric carbon through photosynthesis (Tadesse 2008). For instance, it has been estimated that the forest resources in Ethiopia store 2.76 billion tons of carbon in the aboveground biomass, and the high forests contributed the largest carbon stock (Moges et al. 2010). Recent study has also shown even higher carbon density than previous estimations, particularly in dry Afromontane forests (Yohannes et al. 2015). However, there are large uncertainties regarding the size of standing carbon stocks, especially in the African continent (Chave et al. 2014) and, particularly, in the Ethiopian forests that might be due to the difference in vegetation and soils, topographical heterogeneity, land use, and management systems.

Forest disturbances often lead to changes in stand biomass, productivity, and carbon cycling (Gautam and Mandal 2016). The previous estimation reported that tropical deforestation contributes approximately $15-25 \%$ of the annual global greenhouse gas emissions (Houghton 2005). Similar to deforestation, timber extraction and logging are responsible for just over half of forest degradation (52\%), followed by fuelwood collection and charcoal production (31\%), uncontrolled fire (9\%), and livestock grazing (7\%) in the tropics (Hosonuma et al. 2012). This indicates that deforestation and forest degradation are the largest sources of greenhouse gas emissions in most tropical countries. This suggested that a small disruption in forests might result in a significant change in the global $\mathrm{C}$ cycle. However, the impacts of forest disturbances, particularly harvesting of woody species, on aboveground biomass in dry Afromontane forests of Ethiopia are not well understood. Therefore, the estimation of biomass is an important means for understanding the function of a forest ecosystem and the effect of disturbances on productivity and carbon storage of forest stands.

The forest resources in Ethiopia have been facing intense degradation and deforestation because of agricultural land expansion and overgrazing that result in significant loss of forest biodiversity and ecosystem services (Lemenih et al. 2005; Mengistu et al. 2005). However, the expansion of agricultural land did not completely destruct natural forests. Forest patches have remained, particularly on the steep slopes, churches (Wassie et al. 2005; Aerts et al. 2016), and pockets, which are inaccessible for agricultural and grazing purposes. Owing to their possession of many forest patches, the Ministry of Environment and Forests (MEF) selected two districts, namely Banja and Guangu Districts in northwestern Ethiopia, as strategic sites for reducing the emission of $\mathrm{C}$ from deforestation and forest degradation and enhancement of sustainable forest management (REDD+) (MEF: Pilot REDD+ sites visit report. Federal Democratic Republic of Ethiopia, unpublished). Following the selection of these districts by MEF, there was an urgent action to quantify the carbon stocks accurately to establish the baseline, which will be instrumental in the national efforts of the mitigation of climate change. Such baseline studies of forest carbon stocks help to understand what factors influence forest components in the maintenance of the natural equilibrium level and how to improve their roles as carbon-rich forest ecosystems if the impacts of ongoing anthropogenic and environmental factors continue. This study is, therefore, carried out in the two selected districts aimed at generating the information that MEF needs to monitor and reduce the emission of $\mathrm{C}$ stocks from the forests as well as use it as a pilot study that may be up- and out-scaled if successful.

To understand the impacts of anthropogenic and environmental disturbances on ecosystem services, particularly carbon sequestration in the forests of Ethiopia, most previous studies have focused quantifying carbon stocks in protected areas (Moges et al. 2010; Sahle 2011; Simegn and Soromessa 2015). As a result, local carbon inventories for various tropical Afromontane forest are lacking, leading to the lack of quantifying the relationship between forest biomass and stand structure in Ethiopia. Thus, the objectives of this study were to (i) determine the aboveground biomass of trees and soil carbon stocks, (ii) identify the impact of harvesting of woody species and topographic factors on carbon storage, 
and (iii) understand the relationship between aboveground biomass carbon stocks and stand structures in five Afromontane forests of Awi Zone, northwestern Ethiopia.

\section{Methods}

\section{Description of the study area}

The study was conducted in five dry Afromontane forests in two districts of Awi Zone of Amhara National Regional State (ANRS), northwestern Ethiopia. It is located at the geographical coordinates of $10^{\circ} 30^{\prime}$ to $11^{\circ} 05^{\prime} \mathrm{N}$ and $36^{\circ}$ $20^{\prime}$ to $37^{\circ} 05^{\prime} \mathrm{E}$ (Fig. 1). The two administrative districts (Banja and Guangua) contained many forests. The dominant species mainly found in the forests are Prunus africana (Hook. f.) Kalkm., Albizia gummifera (J.F. Gmel.) C.A. Sm., and Apodytes dimidiata E. Mey. ex Am. (Getaneh Gebeyehu, Teshome Soromessa, Tesfaye Bekele: Species composition, stand structure and regeneration status of tree species in dry Afromontane forests of Awi Zone, northwestern Ethiopia, Submmited). Thus, the four forest sites, namely Apini, Bari, Dabkuli, and Kahtasa forests, in Banja District and the Tsahare Kan forest in Guangua District were selected for the present study. The forests cover a total area of 3188 ha varying from 509.79 in the Dabkuli forest to 724.03 ha in the Tsahare Kan forest (Table 1). They are mainly found on steep and intermediate slopes. The forests located in Banja District are state forests, while the local communities own the Tsahare Kan forest. Currently, the four forests are designated state forests (Apini, Bari, Dabkuli and Kahtasa) which are protected and managed by the government of ANRS since 1994, while the Tsahare Kan forest is managed by the local communities during the last 15 years. Despite these measures, the forests are still under heavy pressure due to free grazing and illegal harvesting of woody species by the local inhabitants. The soils of the highlands of the study areas are largely developed from parent materials of volcanic origin, mainly, reddish or brown in color, draining freely, and of medium to heavy texture. The soils of the area are closely related to their parent materials and their degree of weathering.

\section{Temperature and rainfall}

The study areas exhibit a unimodal pattern of weather condition with an annual precipitation of $2241 \mathrm{~mm}$ and an average temperature of $18.7^{\circ} \mathrm{C}$ registered in the weather station of Kidamaja at "Banja" District and 1679 $\mathrm{mm}$ and an average temperature of $20.8^{\circ} \mathrm{C}$ registered in

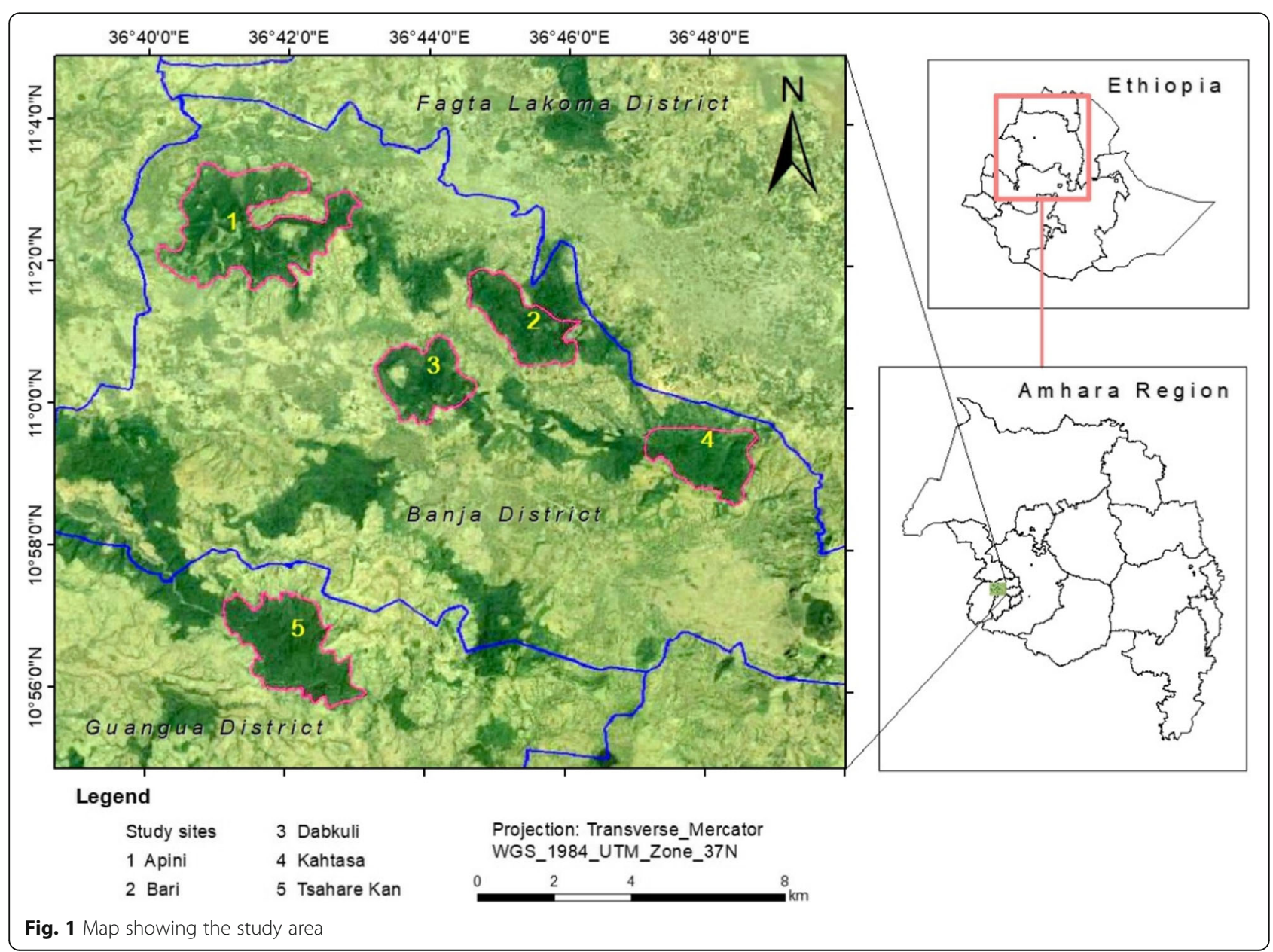


Table 1 Locations and topographic characteristic of the five forests

\begin{tabular}{llllll}
\hline Forest & Cover (ha) & Elevation $(\mathrm{m})$ & Slope (\%) & Aspects & Geographical location \\
\hline Tsahare & 724.03 & $2034 \pm 12.5$ & $12.94 \pm 1.09$ & W, N & $10^{\circ} 56^{\prime}$ to $10^{\circ} 57^{\prime} \mathrm{N}$ and $036^{\circ} 40^{\prime}$ to $036^{\circ} 42^{\prime} \mathrm{E}$ \\
Apini & 693.33 & $2110 \pm 12.7$ & $15.93 \pm 1.89$ & S, SW, W, E & $11^{\circ} 01^{\prime}$ to $11^{\circ} 02^{\prime} \mathrm{N}$ and $036^{\circ} 41^{\prime}$ to $036^{\circ} 42^{\prime} \mathrm{E}$ \\
Dabkuli & 509.79 & $2168 \pm 11.96$ & $21.87 \pm 3.02$ & W, NW, NE, S & $10^{\circ} 59^{\prime}$ to $11^{\circ} 00^{\prime} \mathrm{N}$ and $036^{\circ} 43^{\prime}$ to $036^{\circ} 44^{\prime} \mathrm{E}$ \\
Bari & 720.41 & $2266 \pm 19.55$ & $17.5 \pm 2.62$ & $\mathrm{~S}, \mathrm{SW}$ & $11^{\circ} 00^{\prime}$ to $11^{\circ} 01^{\prime} \mathrm{N}$ and $036^{\circ} 45^{\prime}$ to $036^{\circ} 45^{\prime} \mathrm{E}$ \\
Kahtasa & 540.74 & $2410 \pm 10.54$ & $13.44 \pm 2.53$ & $\mathrm{~S}, \mathrm{~N}, \mathrm{~W}$ & $10^{\circ} 58^{\prime}$ to $10^{\circ} 59^{\prime} \mathrm{N}$ and $036^{\circ} 47^{\prime}$ to $036^{\circ} 48^{\prime} \mathrm{E}$ \\
\hline
\end{tabular}

$S$ south, $W$ west, $N$ north, SW southwest, NE northeast, $N W$ northwest, $E$ east

the weather station of Chagni at "Guangua" District. The maximum precipitation occurs from June to October. The hottest months are experienced in December, January, February, March, and April, while the coldest months occur in June, July, and August (Fig. 2).

\section{Data collection methods}

\section{Sampling design}

The boundaries of quadrats were first marked and determined in the study forests using a global position system (GPS) receiver. Later, $20 \times 20 \mathrm{~m}^{2}\left(400 \mathrm{~m}^{2}\right)$ quadrat sizes were laid out using meter tape along montane forests. Parallel transect lines were established from the top to the bottom of the forests having a distance of $500 \mathrm{~m}$ between each other. The first sampling quadrats were located randomly, and the subsequent quadrats were formed systematically (Kent 2011). Sampling intervals between quadrats were $50 \mathrm{~m}$. The number of sample quadrats in a single stratum with one forest system can be determined in a previously recommended method (Pearson et al. 2007) as:

$$
n=\frac{\left(\sum_{i=1}^{n} N i \times S_{i}\right)^{2}}{\frac{N^{2} \times E^{2}}{t^{2}}+\left(\sum_{i=1}^{n} N i \times S_{i}^{2}\right)}
$$

where $n$ is the number of quadrats and $E$ is the desired level of precision. It is assumed that $10 \%$ of allowable error is calculated by multiplying the mean carbon stock by the desired precision (that is, mean carbon stock $\times 0.1$, for $10 \%$ precision), and $t$ is the sample statistic from the $t$ distribution for the $95 \%$ confidence level; $t$ usually is set at 2 as the sample size is unknown at this stage, $N_{i}$ is the number of sampling units for forest type I (= area of the stratum, in ha/area of the quadrat, in ha), $N$ is the number of sampling units in the population $\left(N=\Sigma N_{i}\right)$, and $S_{i}$ is the standard deviation of forest cover I.

\section{Data collection}

In each data on biomass, 3.2 ha quadrats of $20 \times 20 \mathrm{~m}^{2}$ were established for tree census. Biomass data were collected using a non-destructive method during December 2017. Only stems with a diameter at breast height $(\mathrm{DBH})$ greater than or equal to $5 \mathrm{~cm}$ as the minimum diameter (Pearson et al. 2007) were identified to species in the field and measured for DBH, height, and canopy cover from 80 quadrats ( 5 forests $\times 16$ quadrats). Specimens of unknown species were collected, pressed, and dried for identification. For the tree species having a diameter at breast height (DBH) of $5 \mathrm{~cm}$, their stem diameters were measured over bark using diameter tapes. For multi-stem tree species branching below $\mathrm{DBH}$, the stem diameters of all the stems were measured separately as suggested by Kent (2011). The height and canopy cover of all individual trees were also measured

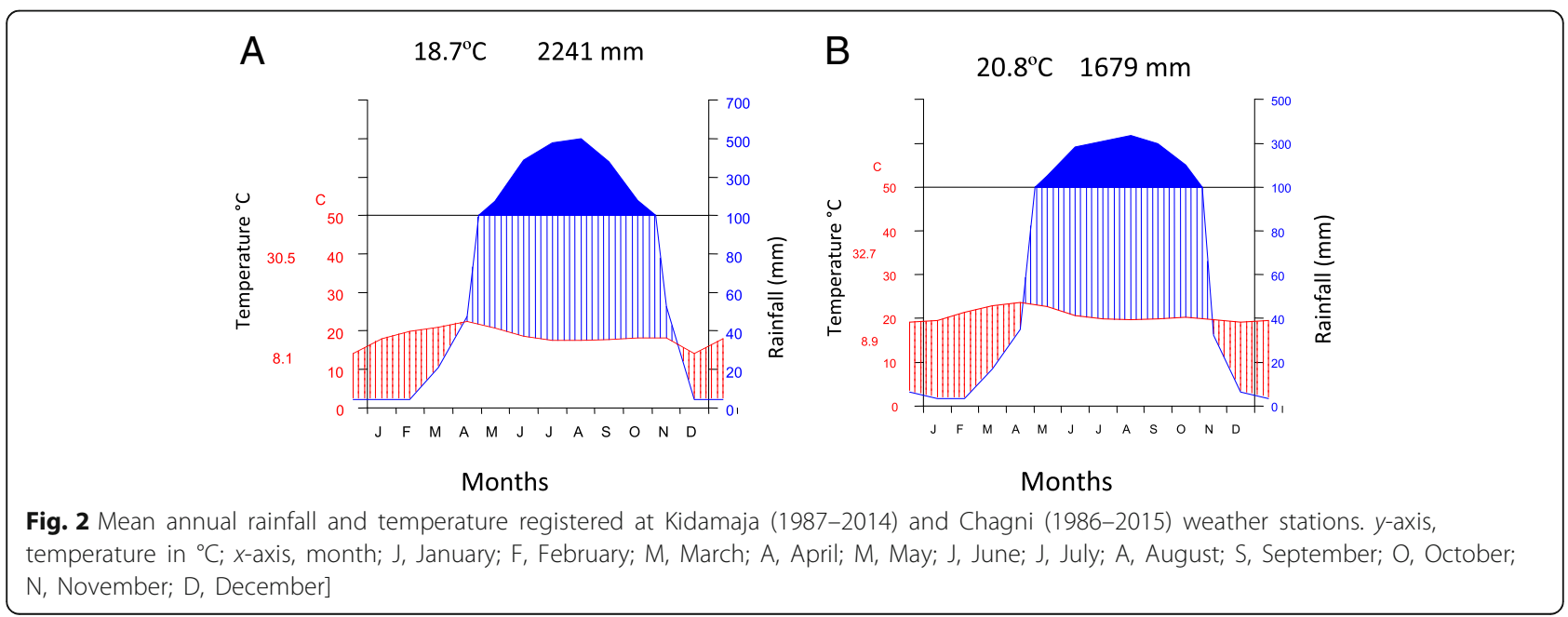


in the sampling quadrats with the help of clinometers and meter tape, respectively. Canopy cover was measured at the north to south and east to west direction up to the longest branch cover using a measuring tape, and their areas were calculated.

\section{Data on environment and disturbance factors}

Environmental and disturbance factors encompassing slope, elevation, aspect, biomass extraction (woody harvesting), and soils were measured and recorded as site description. Slopes and elevations were measured on the four corners of quadrat with measuring tools of clinometers and Garmin GPS, respectively, and then, average values were calculated for site factors. An aspect of quadrats was recorded to identify the orientation of the quadrats in the forests. Estimates of soil carbon stocks to single depth bulk density are mostly biased (Lee et al. 2009). Therefore, to improve the accuracy and reduction of bias, soil samples were collected using an auger at the four corners (four replications) of the quadrats with two samples at $0-15$ and $15-30 \mathrm{~cm}$ depth. The sampling depth to determine carbon content was $30 \mathrm{~cm}$ because it is suggested as the default sampling depth for forest soil (IPCC 2006). A total of 160 soil samples (2 depths $\times 80$ quadrats) were collected for the determination of soil $\mathrm{pH}$, the concentrations of organic carbon $(\mathrm{OC})$, and the total nitrogen (TN). About $300 \mathrm{~g}$ of soil samples was collected on each depth for chemical analysis. The samples from each of the two depths were composited separately, labeled, placed in double plastic bags, and transported to the laboratory in Water Works Design and Supervision Enterprise (WWDSE) in Addis Ababa, Ethiopia. Similarly, a total of 160 soil samples (2 depths $\times 80$ quadrats) were collected on the center of the quadrats using a stainless core sampler to determine soil bulk density. The content of soils in the core sampler was, then, placed in plastic bags, and the samples were transported to the laboratory for dry weight determination. The number of stumps and associated canopy opening was recorded in each quadrat as disturbance factors. Canopy opening was measured using a densiometer by standing in the center of the main quadrat. In this study, the effect of the severity of disturbances (harvesting and canopy openness due to removal of trees with stem diameter $\geq 5 \mathrm{~cm}$ ) on carbon stocks is assessed, but effects of their timing and frequency could not be assessed.

\section{Soil laboratory analyses}

The soil samples were analyzed in the soil fertility laboratory of the Water Works Design and Supervision Enterprise (WWDSE) in Addis Ababa, Ethiopia. Soil pH was determined in 1:2.5 pH- $\mathrm{H}_{2} \mathrm{O}$ using the Beckman Zeromatic-II pH meter. Soil organic carbon (SOC) and total nitrogen (TN) contents were determined by
Walkley and Black (1934) and micro-Kjeldahl methods (Nelson and Sommers 1996), respectively. Carbon to N ratio $(\mathrm{C} / \mathrm{N})$ was calculated based on $\mathrm{C}$ and $\mathrm{N}$ concentrations. The mass of each soil sample (MS) was determined using oven-dry adjusted at a temperature of $105^{\circ}$ $\mathrm{C}$ for $24 \mathrm{~h}$ to achieve a constant weight (Pearson et al. 2007). The volume of core sampler (VC) was determined as VS $=\pi r^{2} h$, where $r$ is the radius and $h$ is the height of core sampler $\left(\mathrm{VC}=3.14 \times(2.5 \mathrm{~cm})^{2} \times 5 \mathrm{~cm}=98.125\right.$ $\mathrm{cm}^{3}$ ). When small stones appeared in the samples, they were separated from each soil sample, their mass was weighted, and the volume was determined using a water displacement method.

\section{Data analyses}

\section{Calculation of biomass and carbon stocks}

All data were analyzed using $\mathrm{R}$ software ( $\mathrm{R}$ Core Team 2016). Before analyzing the data, a preliminary analysis was conducted to ensure a normal distribution using Shapiro-Wilk's statistical test. When and if distributions were not normal, $\log$ transformation was employed. Aboveground biomass of trees (AGB) was calculated using a previously published allometric equation where stem diameter $(D, \mathrm{~cm})$, height $(H, \mathrm{~m})$, and wood density $\left(p, \mathrm{~g} \mathrm{~cm}^{-3}\right)$ were used as independent variables (predictors). The Global Wood Density database was used for sourcing the wood density of species (Zanne et al. 2009). AGB was calculated with the BIOMASS package in $\mathrm{R}$ (Réjou-Méchain et al. 2017) using the following formula (Chave et al. 2014):

$$
\operatorname{AGB}(\mathrm{kg})=0.0673 \times\left(p D^{2} H\right)^{0.976}
$$

where AGB is the aboveground biomass of trees $(\mathrm{kg})$, $p$ is the specific wood density $\left(\mathrm{g} \mathrm{cm}^{-3}\right), D$ is the stem diameter at breast height $(\mathrm{cm})$, and $H$ is thetotal height of trees $(\mathrm{m})$. Biomass carbon was determined by assuming $50 \%$ of AGB containing carbon (IPCC 2006). Total AGB carbon for each quadrat was calculated by summing AGB carbon for all trees. Carbon stocks were determined for each quadrat and then extrapolated to megagrams per hectare. Belowground biomass (BB) is also one of the most common descriptors of the relationship between the root (belowground) and shoot (aboveground) biomass. To simplify the process for estimating belowground biomass, the root-to-shoot ratio value of 1:5 was recommended (Pearson et al. 2007), i.e., to estimate belowground biomass as $20 \%$ of aboveground tree biomass.

\section{Soil carbon and nitrogen stocks}

The amount of carbon and nitrogen stored per hectare was obtained considering soil depth $(\mathrm{cm})$, bulk density $\left(\mathrm{g} \mathrm{cm}^{-3}\right)$, and the percentage of soil organic carbon 
content (SOC) and total nitrogen (TN) in the recommended method (Pearson et al. 2007), using the following formula:

$$
\begin{aligned}
\text { SOC or TN stocks }= & \mathrm{BD} \times d \times \% \text { SOC or TN }(\%) \\
& \times \mathrm{CF}
\end{aligned}
$$

where SOC stocks is the soil organic carbon stock per unit area $\left(\mathrm{Mg} \mathrm{ha}^{-1}\right)$, TN stocks is the total nitrogen stocks $\left(\mathrm{Mg} \mathrm{ha}^{-1}\right)$, BDis the bulk density $\left(\mathrm{g} \mathrm{cm}^{-3}\right), d$ is the total depth at which the sample was taken $(\mathrm{cm})$, $\% \mathrm{SOC}$ is the soil organic carbon concentration, $\mathrm{TN}(\%)$ is the total nitrogen concentration, and $\mathrm{CF}$ is the coefficient to discount rock fragments. However, CF is applicable for rock soil samples, not the case of the samples in small soil particles. Thus, it was excluded from the calculation. In this study, the soil carbon stock was evaluated based on fine soil fraction and to a depth of $30 \mathrm{~cm}$. Bulk density (BD) was derived from the following equation:

$$
\mathrm{BD}=\frac{\mathrm{MS}}{\mathrm{VC}}
$$

where BD isbulk density $\left(\mathrm{g} \mathrm{cm}^{-3}\right)$, MS is the mass of the oven-dry soil (g), and VC is the volume of the core sampler $\left(\mathrm{cm}^{3}\right)$. However, some soil samples contained small stones, and in this case, $\mathrm{BD}$ was determined as follows:

$$
\mathrm{BD}=\frac{\mathrm{MS}-\mathrm{MSS}}{\mathrm{VC}-\mathrm{VS}}
$$

where BD is the bulk density $\left(\mathrm{g} \mathrm{cm}^{-3}\right)$, MS is the mass of the oven-dry soil (g), MSS is the mass of stones (g), $\mathrm{VC}$ is the volume of core sampler $\left(\mathrm{cm}^{3}\right)$, and VS is the volume of stones $\left(\mathrm{cm}^{3}\right)$. The analysis of variance (ANOVA) was employed to test the significant differences of soil carbon stocks between depths. Means of carbon stocks in forests that exhibited differences were compared using Tukey's Honestly Significant Test at a significance level of $5 \%$. The carbon stock density was calculated by summing the carbon stock densities of the individual carbon pools of that stratum. The total carbon stock was then converted to tons of $\mathrm{CO}_{2}$ equivalent by multiplying it with 3.67 (Pearson et al. 2007).

\section{Correlation and regression analyses}

The relation between carbon stocks and site factors was determined through correlation analysis to understand their cause and effect. The study used the basal area $\left(\mathrm{m}^{2}\right)=\pi d^{2} / 4(10,000)$ (Husch et al. 2003), stem diameter, total height, and canopy cover as stand structures. A regression analysis was employed to explore the spatial relationship between AGB carbon stocks and biotic factors (stand structures), abiotic factors (soil variables, elevation, and slope), and disturbance index. The disturbance index was calculated as the ratio of the sum of the density of stumps to total density (stumps + live individuals) (Sagar et al. 2003). All statistical significances were decided at $5 \%$ of a significant level.

\section{Results}

\section{Aboveground biomass and carbon stocks}

The result revealed that a total of 1655 individuals $(\mathrm{DBH} \geq 5 \mathrm{~cm})$, representing 38 species in 28 families, were identified and measured in the 5 study forests (Additional file 1: Table S1A-E). The density of trees varied among five forests, ranging from 365.6 stem ha ${ }^{-1}$ in Dabkuli to 664.1 stem ha $^{-1}$ in Tsahare Kan forests (Table 2).The stem diameter and height of individual trees varied among forests, with a mean of $21.4 \pm 0.5 \mathrm{~cm}$ and $11.3 \pm 0.11 \mathrm{~m}$, respectively. The aboveground biomass (AGB) and carbon stocks varied greatly, reflecting a declining trend from the least-disturbed Bari forest (269.09 Mg C ha ${ }^{-1}$ ) to highly disturbed Kahtasa forest $\left(140.80 \mathrm{Mg} \mathrm{C} \mathrm{ha}{ }^{-1}\right)$, and the difference was statistically significant $(F=4.79, P<0.05)$ (Table 2). This disturbance level equates to a decrease in carbon stocks of $36.8 \%$ in the highly disturbed compared with the least-disturbed forest. The overall difference between these two forest sites was due to the presence of large stem diameter and height of species in Bari than Kahtasa forest.

\section{Variation of biomass carbon stocks between stem diameter class}

The relation between stem density and aboveground biomass carbon stocks (AGB CS) showed that the smaller size classes held most of the stems but contributed to a small fraction of the live AGB CS. Therefore, the largest proportions of AGB CS $\left(\mathrm{Mg} \mathrm{ha}^{-1}\right)$ were found in the large stem diameter class $(\mathrm{DBH} \geq 50 \mathrm{~cm})$, i.e., $53.2 \%$ in Tsahare Kan, $76.2 \%$ in Apini, $79.8 \%$ in Dabkuli, $51.7 \%$ in Bari, and $46.5 \%$ in Kahatsa forests (Fig. 3). This implies that the harvesting of large-sized trees, particularly in the Kahtasa forest, leads to the reduction of carbon stocks. Hence, the protection and proper management of stand structures would enhance AGB CS in the study forests.

\section{Variation of biomass carbon stocks among species}

The result demonstrates that the dominant species, namely Albizia gummifera, Apodytes dimidiata, and Prunus africana, contributed the highest AGB CS in each of the study forests (Table 3). Albizia gummifera (123.1 Mg C ha $\left.{ }^{-1}, 72.4 \%\right)$ contributed the highest AGB CS in the Tsahare Kan forest. Albizia gummifera and Prunus africana stored 22.9 and $36.5 \%$ of AGB CS in Apini forest, respectively. Albizia gummifera, Apodytes dimidiata, and Prunus africana together accounted for the highest AGB CS of $71.2 \%$ in Dabkuli and $81.3 \%$ in 
Table 2 Aboveground biomass and carbon stocks in the five forests

\begin{tabular}{lllllll}
\hline Forest & Density $\left(\right.$ stem ha $\left.{ }^{-1}\right)$ & $\begin{array}{l}\text { DBH } \\
(\mathrm{cm})\end{array}$ & $\begin{array}{l}\text { Height } \\
(\mathrm{m})\end{array}$ & $\begin{array}{l}\text { AGB CS } \\
\left(\mathrm{Mg} \mathrm{ha}^{-1}\right)\end{array}$ & $\begin{array}{l}\mathrm{Dl} \\
(\%)\end{array}$ & $\begin{array}{l}F \text { value } \\
P \text { value }\end{array}$ \\
\hline Tsahare & 664.1 & $17.5 \pm 0.8$ & $11.4 \pm 0.2$ & $170.09 \pm 31.9^{\mathrm{a}}$ & $16.8 \pm 0.04$ & 0.15 \\
Apini & 434.4 & $20.8 \pm 1.2$ & $11.1 \pm 0.2$ & $171.21 \pm 51.3^{\mathrm{a}}$ & $18.6 \pm 0.03$ & 0.85 \\
Dabkuli & 365.6 & $24.5 \pm 1.5$ & $11.7 \pm 0.3$ & $207.35 \pm 47.2^{\mathrm{a}}$ & $19.8 \pm 0.04$ & \\
Bari & 620.3 & $25.9 \pm 0.9$ & $12.2 \pm 0.2$ & $269.09 \pm 46.8^{\mathrm{b}}$ & $13.3 \pm 0.01$ & 4.79 \\
Kahtasa & 501.6 & $19.5 \pm 0.9$ & $10.4 \pm 0.3$ & $140.8 \pm 37.1^{\mathrm{a}}$ & $22.1 \pm 0.03$ & 0.04 \\
Mean \pm SE & $517.2 \pm 55.8$ & $21.4 \pm 0.5$ & $11.3 \pm 0.11$ & $191.6 \pm 19.7$ & $18.1 \pm 0.01$ & \\
\hline
\end{tabular}

For all the forests, values are mean \pm standard error. $D B H$ stem diameter at breast height, $N=16$, number of quadrats, $A G B C S$ aboveground biomass carbon stocks, $\mathrm{Dl}$ disturbance index ( $\mathrm{DI}<15 \%$, least disturbed; $\mathrm{DI}=15-20 \%$, medium disturbed; and $\mathrm{DI}>20 \%$, highly disturbed). Different letters in the same column show statistically significant differences (Tukey's Honestly Significant Test at $P<0.05$ )

Bari. Albizia gummifera and Apodytes dimidiata together accounted for $54.1 \%$ of AGB CS in the Kahtasa forest. The overall high contribution of AGB CS by these dominant species was due to the greater abundance of large diameters and height of the species. The species, which contributed less than $1 \mathrm{Mg} \mathrm{ha}^{-1}$ of AGB CS, were $11,11,8,5$, and 10 in the sites of Tsahare Kan, Apini, Dabkuli, Bari and Kahatsa forests, respectively (Additional file 1: Table S1A-E). The remaining proportion of the AGB CS was contributed by the other tree species recorded in the quadrats.

\section{Vertical distribution of soil variables}

The result revealed that soil properties and carbon stocks differed widely among the five studied forests (Table 4). The soil organic carbon and total nitrogen concentrations decreased but bulk density and $\mathrm{pH}$ increased along the depth. Mean concentration of SOC for $0-15$ to $15-30 \mathrm{~cm}$ soil depths decreased from 8.64 to 6.53 in the Kahtasa forest and 5.66 to 3.21 in the Tsahare
Kan forest, respectively. Similar to this, the mean TN concentration on topsoil to subsoil layer decreased from 0.83 to 0.65 in the Kahtasa forest and 0.46 to 0.25 in the Tsahare Kan forest, respectively. The analysis in the study revealed that the concentration of SOC and TN varied significantly $(P<0.05)$ between the topsoil $(0-15$ $\mathrm{cm})$ and subsoil $(15-30 \mathrm{~cm})$ layers in Tsahare Kan and Kahtasa forests while it did not vary significantly in the other study forests.

Mean bulk density for $0-15$ to $15-30 \mathrm{~cm}$ soil depths increased from 0.61 to $0.76 \mathrm{~g} \mathrm{~cm}^{-3}$ in the Bari forest, 0.71 to $0.91 \mathrm{~g} \mathrm{~cm}^{-3}$ in the Dabkuli forest, and 0.79 to $0.93 \mathrm{~g} \mathrm{~cm}^{-3}$ in the Apini forest, respectively. The analysis of bulk density between the topsoil and subsoil layer varied significantly $(P<0.05)$ in all the study forests except the Tsahare Kan forest. In contrast, soil $\mathrm{pH}$ value increased on topsoil to subsoil layer from 5.96 to 6.08 in the Tsahare Kan forest and very small variations from 5.04 to 5.05 in the Bari forest. In the meanwhile, carbon to nitrogen ratio decreased for $0-15$ to $15-30 \mathrm{~cm}$ soil

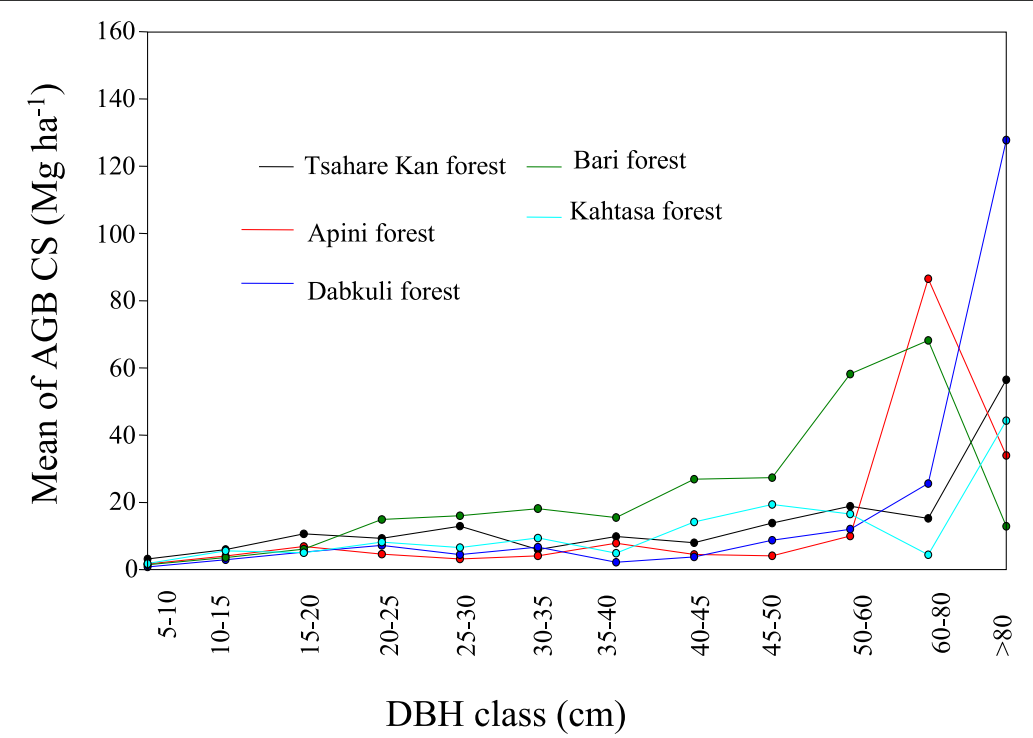

Fig. 3 Variation of AGB CS in stem diameter at breast height (DBH) class of species in the five forests 
Table 3 Mean aboveground biomass carbon stocks of dominant and co-dominant species in the five forests

\begin{tabular}{|c|c|c|c|c|c|}
\hline \multirow[t]{2}{*}{ Species } & \multicolumn{5}{|c|}{ AGB CS $\left(\mathrm{Mg} \mathrm{ha}^{-1}\right)$ of forest } \\
\hline & Tsahare Kan & Apini & Dabkuli & Bari & Kahtasa \\
\hline Albizia gummifera (J.F. Gmel.) C.A. Sm. & 123.1 & 39.2 & 44.7 & 74.5 & 21.9 \\
\hline Allophyllus abyssinicus (Hochst.) Radlkofer & 0.5 & 7.6 & 16.1 & 7.7 & 2.2 \\
\hline Apodytes dimidiata E. Mey. ex Am. & 0.2 & 33.2 & 43.5 & 58.8 & 54.2 \\
\hline Croton macrostachus Del. & 8.6 & 6.9 & 7.8 & 4.7 & 1.5 \\
\hline Prunus africana (Hook. f.) Kalkm. & 0.1 & 62.4 & 59.5 & 87.0 & 1.9 \\
\hline Total AGB CS $\left(\mathrm{Mg} \mathrm{ha}^{-1}\right)$ & 132.5 & 149.3 & 171.6 & 232.7 & 81.7 \\
\hline Proportion (\%) & 77.6 & 87.2 & 82.7 & 86.5 & 58.0 \\
\hline
\end{tabular}

$A G B C S$ above ground biomass carbon stock

depths from 12.51 to 10.69 in the Tsahare Kan forest and 9.83 to 9.56 in the Bari forest, respectively. The analysis in the result of soil $\mathrm{pH}$ and carbon to nitrogen ratio did not show significant differences between the topsoil and subsoil layers in all the study forests. This temporal dynamics of soil $\mathrm{pH}$ and the $\mathrm{C}$ to $\mathrm{N}$ ratio showed slight differences among various forests. The lower amount of bulk density, soil $\mathrm{pH}$ value, and a higher concentration of SOC and TN in the topsoil revealed the presence of a better organic matter and porosity for root growth than the subsoil layers.

\section{Horizontal distribution of soil variables}

The regression analyses revealed that both concentrations of SOC $\left(\operatorname{adj} . R^{2}=0.22, P<0.05\right)$ and TN $\left(\operatorname{adj} . R^{2}=0.24\right.$, $P<0.05)$ decreased significantly with increasing soil $\mathrm{pH}$ values (Fig. 4a, b). On the other hand, SOC (adj. $R^{2}=0.27$, $P<0.05)$ (Fig. 4c) and TN (adj. $\left.R^{2}=0.19, P<0.05\right)($ Fig. $4 \mathrm{~d})$ concentrations increased along increasing elevation due to relatively higher moisture levels and lower temperatures at the higher elevation. This slowed down the decomposition of organic matter on the higher elevation. Similarly, SOC (adj. $R^{2}=0.12, P<0.05$ ) and TN concentrations (adj. $\left.R^{2}=0.12, P<0.05\right)$ exhibited a positive response in the increasing canopy cover of species (Fig. 4e, f). This indicates that the protection of canopy of the forests resulted in an increase of organic matter whereas removing of canopy cover would result in the decline of organic matter.

\section{Soil organic carbon and nitrogen stocks}

Soil organic carbon and nitrogen stocks varied in the vertical and spatial distribution of forests (Table 4). The highest mean SOC stocks for $0-15$ to $15-30 \mathrm{~cm}$ soil depths (90.32 to $78.03 \mathrm{Mg} \mathrm{C}^{-1}$ ) and the lowest SOC stocks (61.59 to $39.05 \mathrm{Mg} \mathrm{C} \mathrm{ha}{ }^{-1}$ ) were found in Bari and Tsahare Kan forests, respectively. This indicates that the range of 53.65 to $58.86 \%$ of the SOC stock was found in the topsoil layer. Like this, the highest mean

Table 4 Soil physicochemical properties and carbon stocks of the study forests

\begin{tabular}{|c|c|c|c|c|c|c|}
\hline \multirow[t]{2}{*}{ Parameter } & \multirow{2}{*}{$\begin{array}{l}\text { Depth } \\
(\mathrm{cm})\end{array}$} & \multicolumn{5}{|l|}{ Forest } \\
\hline & & Tsahare Kan & Apini & Dabkuli & Bari & Kahtasa \\
\hline \multirow[t]{2}{*}{ Soil pH } & $0-15$ & $5.96 \pm 0.09$ & $5.91 \pm 0.11$ & $5.75 \pm 0.12$ & $5.04 \pm 0.08$ & $5.07 \pm 0.06$ \\
\hline & $15-30$ & $6.08 \pm 0.06$ & $5.89 \pm 0.14$ & $5.79 \pm 0.13$ & $5.05 \pm 0.08$ & $5.22 \pm 0.12$ \\
\hline \multirow[t]{2}{*}{ SOC (\%) } & $0-15$ & $5.66 \pm 0.28^{a}$ & $6.93 \pm 0.64$ & $6.77 \pm 0.48^{\mathrm{a}}$ & $9.09 \pm 0.68$ & $8.64 \pm 0.57^{\mathrm{a}}$ \\
\hline & $15-30$ & $3.21 \pm 0.21^{b}$ & $6.49 \pm 0.95$ & $4.94 \pm 0.54^{b}$ & $7.22 \pm 0.88$ & $6.53 \pm 0.58^{b}$ \\
\hline \multirow[t]{2}{*}{ TN (\%) } & $0-15$ & $0.46 \pm 0.03^{\mathrm{a}}$ & $0.72 \pm 0.09$ & $0.63 \pm 0.07$ & $0.94 \pm 0.07$ & $0.83 \pm 0.05^{\mathrm{a}}$ \\
\hline & $15-30$ & $0.25 \pm 0.02^{b}$ & $0.63 \pm 0.11$ & $0.53 \pm 0.08$ & $0.77 \pm 0.09$ & $0.65 \pm 0.05^{b}$ \\
\hline \multirow[t]{2}{*}{$C: N$} & $0-15$ & $12.51 \pm 0.40$ & $10.69 \pm 0.60$ & $11.93 \pm 0.80$ & $9.83 \pm 0.40$ & $10.55 \pm 0.54$ \\
\hline & $15-30$ & $12.96 \pm 0.47$ & $11.64 \pm 0.88$ & $10.59 \pm 0.64$ & $9.56 \pm 0.30$ & $10.12 \pm 0.33$ \\
\hline \multirow[t]{2}{*}{$\mathrm{BD}\left(\mathrm{g} \mathrm{cm}^{-3}\right)$} & $0-15$ & $0.73 \pm 0.03^{\mathrm{a}}$ & $0.79 \pm 0.03^{\mathrm{a}}$ & $0.71 \pm 0.03^{\mathrm{a}}$ & $0.61 \pm 0.03^{\mathrm{a}}$ & $0.70 \pm 0.02^{\mathrm{a}}$ \\
\hline & $15-30$ & $0.82 \pm 0.03^{\mathrm{a}}$ & $0.93 \pm 0.02^{b}$ & $0.91 \pm 0.03^{b}$ & $0.76 \pm 0.31^{b}$ & $0.80 \pm 0.02^{b}$ \\
\hline \multirow[t]{2}{*}{ TN stock (Mg ha $\left.{ }^{-1}\right)$} & $0-15$ & $5.05 \pm 0.36^{a}$ & $8.74 \pm 1.34$ & $6.69 \pm 0.87$ & $8.63 \pm 0.78$ & $8.69 \pm 0.57$ \\
\hline & $15-30$ & $3.09 \pm 0.26^{b}$ & $9.03 \pm 1.68$ & $7.16 \pm 1.08$ & $8.72 \pm 1.09$ & $7.75 \pm 0.59$ \\
\hline \multirow[t]{2}{*}{ SOC stock (Mg ha $\left.{ }^{-1}\right)$} & $0-15$ & $61.59 \pm 3.36^{a}$ & $82.58 \pm 8.46$ & $71.46 \pm 5.89$ & $82.92 \pm 7.52$ & $90.32 \pm 6.32$ \\
\hline & $15-30$ & $39.05 \pm 2.85^{b}$ & $92.49 \pm 14.7$ & $66.70 \pm 7.04$ & $81.39 \pm 9.94$ & $78.03 \pm 6.63$ \\
\hline
\end{tabular}

The different letter showed significant difference on vertical and horizontal layers, respectively, using Tukey's pairwise comparisons test at significant level of $5 \%$. $S O C$ soil organic carbon, $T N$ total nitrogen, $B D$ bulk density, $C: N$ carbon to nitrogen ratio. Values are means and standard errors (mean $\pm S E$ ) 
A $\operatorname{SOC}(\%)=-2.188 \mathrm{pH}+18.75$ adj. $\mathrm{R}^{2}=0.22, \mathrm{P}<0.05$

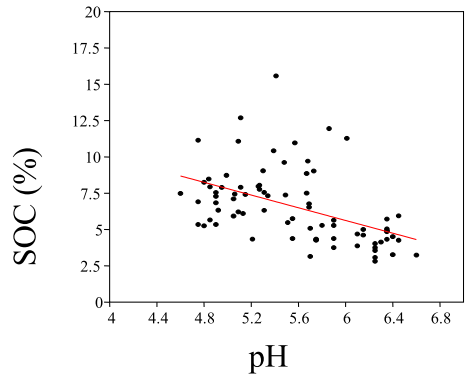

C $\operatorname{SOC}(\%)=0.009279 \mathrm{Elt}-13.85$ adj. $R^{2}=0.27, P<0.05$

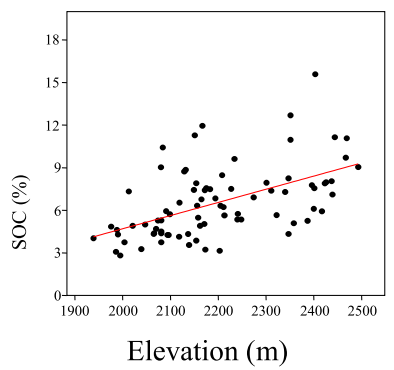

E

$\operatorname{SOC}(\%)=0.1028 \mathrm{CC}(\%)+5.326$ adj. $\mathrm{R}^{2}=0.12, \mathrm{P}=\mathrm{P}<0.05$
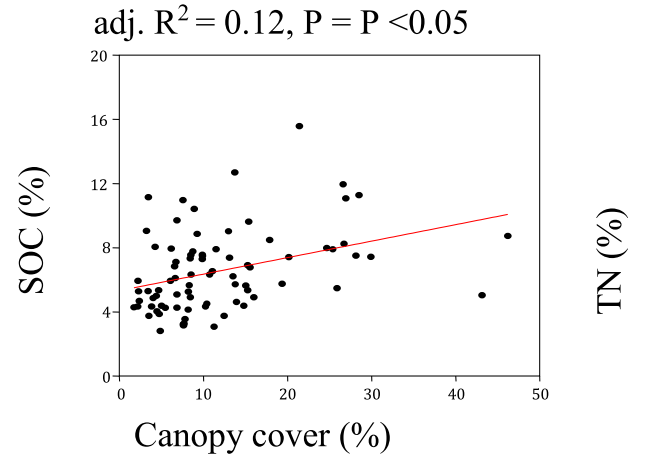

$\mathrm{B}_{\mathrm{TN}}(\%)=-0.2926 \mathrm{pH}+2.263$

$\operatorname{adj} . \mathrm{R}^{2}=0.24, \mathrm{P}<0.05$

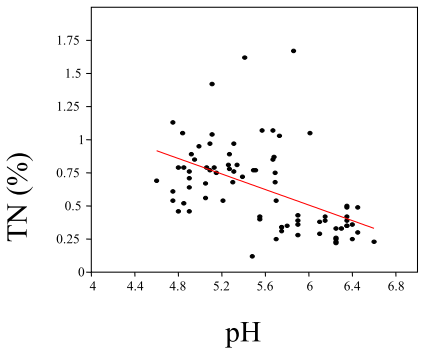

D $\mathrm{TN}(\%)=0.001016 \mathrm{Elt}-1.604$ adj. $\mathrm{R}^{2}=0.19, \mathrm{P}<0.05$

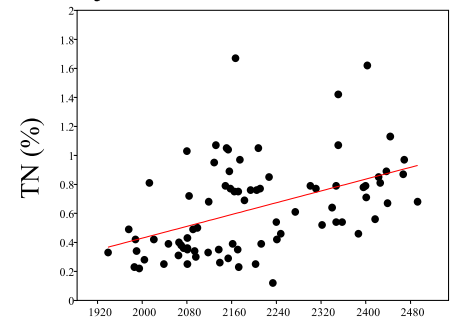

Elevation (m)
$\mathrm{TN}(\%)=0.01315 \mathrm{CC}(\%)+0.4749$

F

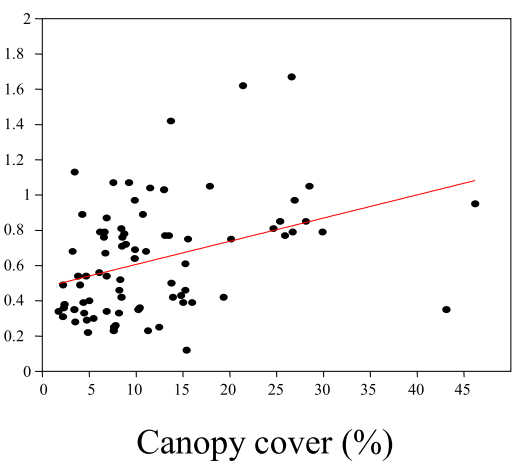

Fig. 4 Relation between mean soil organic carbon (SOC) and total nitrogen (TN) concentrations $(0-30 \mathrm{~cm})$ and site factors (each dot and lines correspond to the observed and fitted values). CC Canopy cover, Elv elevation and adj.R $R^{2}$ adjusted $R^{2}$

TN stocks for $0-15$ to $15-30 \mathrm{~cm}$ soil depths $(8.74$ to $9.03 \mathrm{Mg} \mathrm{C} \mathrm{ha}{ }^{-1}$ ) and the lowest TN stocks (5.05 to 3.09 $\mathrm{Mg} \mathrm{C} \mathrm{ha}{ }^{-1}$ ) were found in Apini and Tsahare Kan forests, respectively. The results showed that they did not detect a significant variation between SOC and TN stocks along the vertical depth in most forests. However, the quantity of SOC and TN stocks was higher in the topsoil of the Tsahare Kan forest, and the difference was statistically significant $(P<0.05)$, reflecting that the soil might have poor organic material than the other forest sites. In contrast, SOC stocks in the topsoil were lower than in the subsoil layers in the Apini forest, suggesting soil degradation appearing in the topsoil of the forest.

Total carbon stocks and sequestration of carbon dioxide The mean AGB CS and SOC stock $(0-30 \mathrm{~cm})$ at 5 forests were $191.6 \pm 19.7$ and $149.32 \pm 6.8 \mathrm{Mg} \mathrm{C} \mathrm{ha}^{-1}$, respectively (Table 5). This indicated that AGB CS were higher than SOC stocks of forests. Conversely, the SOC stocks in the Kahtasa and Apini forest were higher than AGB CS, reflecting that illegal biomass extraction contributes to the reduction of AGB CS. The soil carbon 
stocks in the Tsahare $\operatorname{Kan}\left(100.6 \pm 4.5 \mathrm{Mg} \mathrm{C} \mathrm{ha}{ }^{-1}\right)$ and Apini $\left(175.1 \pm 21.1 \mathrm{Mg} \mathrm{C} \mathrm{ha}^{-1}\right)$ forests were accounted for the lowest and highest carbon stocks, respectively (Table 5). As reflected in the standard errors, the variation in SOC stocks between quadrats was greater at the Apini forest, reflecting the uneven distribution. The SOC stocks in the Tsahare Kan forest were lower than the other four forests. The lowest total carbon stocks $\left(305.8 \pm 38.8 \mathrm{Mg} \mathrm{C} \mathrm{ha}{ }^{-1}\right)$ and $\mathrm{CO}_{2}$ sequestration $\left(1129.5 \pm 142.2 \mathrm{Mg} \mathrm{ha}{ }^{-1}\right.$ of $\left.\mathrm{CO}_{2}\right)$ were stored in the Tsahare Kan forest. In contrast, the total carbon stocks $\left(487.3 \pm 63 \mathrm{Mg} \mathrm{C}\right.$ ha $\left.^{-1}\right)$ and $\mathrm{CO}_{2}$ sequestration $\left(1799.1 \pm 231.1 \mathrm{Mg} \mathrm{ha}^{-1}\right.$ of $\left.\mathrm{CO}_{2}\right)$ in the least-disturbed Bari forest were higher than the other forests. This indicates that management of the study forests would improve stand structure and carbon sequestration potential of the forests. Since belowground biomass and carbon stocks were computed based on AGB values, belowground biomass, as well as carbon stocks, exhibited a similar trend in all forests.

\section{Relation of AGB CS with the basal area, canopy cover, stem diameter, and height}

The relation of aboveground biomass carbon stocks (AGB CS) with the basal area, canopy cover, stem diameter, and height showed two patterns, i.e., linear and quadratic regression (Fig. 5). The descriptive values of stand structures are displayed in Additional file 1: Table S2. The quantity of AGB CS of trees varied considerably among quadrats, ranging from 3.21 to $807.32 \mathrm{Mg} \mathrm{ha}^{-1}$ $\left(191.6 \pm 19.7 \mathrm{Mg} \mathrm{ha}^{-1}\right)$. The canopy cover of trees ranged from 1.19 to $46.19 \%$ among quadrats $(11.9 \pm 0.9 \%)$. The relation of AGB CS and canopy cover (CC) was positively linear (adj. $R^{2}=0.30, P<0.05$ ). This suggests that the protection and management of forests would improve stand structures like the size of the canopy cover and thus facilitate sequestration of carbon dioxide. The basal area of species varied greatly among quadrats, ranging from 0.05 to $3.79 \mathrm{~m}^{2} \mathrm{ha}^{-1}\left(1.29 \pm 0.09 \mathrm{~m}^{2} \mathrm{ha}^{-1}\right)$, and was significantly correlated with AGB CS (adj. $R^{2}=$ $0.96, P<0.05)$. From all stand structures, the AGB CS of trees exhibited highly significant correlation with stem diameter at breast height $\left(\operatorname{adj} . R^{2}=0.98, P<0.05\right)$ and total height (adj. $\left.R^{2}=0.79, P<0.05\right)$ at $P<0.05$. This revealed that the basal area, stem diameter, and total height of species satisfactorily explained the variation in aboveground biomass of the study forests. It also indicated that increasing stand structures would enhance the productivity of forests.

\section{Correlation between carbon stocks and site factors}

Pearson correlation $(r)$ analysis revealed that different site factors cause either positive or negative effects on carbon stocks (Table 6). The AGB CS exhibited a positive relationship with SOC stock $(r=0.29)$ and TN $(r=0.38)$. Similarly, the canopy cover of trees showed a positive correlation with AGB carbon $(r=0.71)$, SOC $(r=0.29)$, and TN $(r=0.26)$ stocks at $P<0.05$. This indicates that stand attributes seem to be general predictors of soil organic carbon stock. On the other hand, the forest canopy openness exhibited a weak negative correlation with AGB carbon $(r=-0.16)$ and SOC $(r=-0.14)$ stocks. With regard to topographic factors, AGB and soil carbon stocks showed a positive correlation to elevation and slope at $P<0.05$.

\section{Spatial distribution of carbon stocks in response to elevation and soil $\mathrm{pH}$}

The results revealed that AGB CS attained unimodal pattern (adj. $R^{2}=0.04, P>0.05$ ) (Fig. 6a), but SOC stocks (adj. $\left.R^{2}=0.12, P<0.05\right)$ increased linearly along elevation (Fig. 6b). The reason for the weak association might be due to the short elevation range of the forest sites. The results also exhibited that the spatial distribution of SOC (adj. $R^{2}=0.11, P<0.05$ ) (Fig. 6c) and TN stocks (adj. $R^{2}=0.13, P<0.05$ ) (Fig. $6 \mathrm{~d}$ ) attained unimodal pattern in response to the soil $\mathrm{pH}$. This relation clearly demonstrates that moderate level of soil acidity enhances SOC and TN stocks.

\section{Variation of carbon stocks in response to topographical factors}

The AGB and SOC stocks exhibited variations in response to elevation, slope, and aspects of the study forests (Table 7). The highest and lowest mean AGB CS were found in the lower $\left(138.1 \pm 23.3 \mathrm{Mg} \mathrm{C} \mathrm{ha}{ }^{-1}\right)$ and

Table 5 Total carbon stocks ( $\mathrm{Mg} \mathrm{ha}^{-1}$ ) and $\mathrm{CO}_{2}$ sequestration (tons of $\mathrm{CO}_{2}$ seq.) of the five forests

\begin{tabular}{llllll}
\hline $\begin{array}{l}\text { Carbon } \\
\text { pool }\end{array}$ & \multicolumn{4}{l}{ Carbon stocks and sequestration of forest } \\
\cline { 2 - 6 } & \multicolumn{1}{l}{ Tsahare Kan } & Apini & Dabkuli & Bari & Kahatsa \\
\hline AGB & $170.1 \pm 31.9$ & $171.2 \pm 51.3$ & $207.4 \pm 47.2$ & $269.1 \pm 46.8$ & $140.8 \pm 37.1$ \\
BB & $34.0 \pm 6.4$ & $34.2 \pm 10.3$ & $41.5 \pm 9.4$ & $53.8 \pm 9.4$ & $27.7 \pm 7.4$ \\
SOC & $100.6 \pm 4.5$ & $175.1 \pm 21.1$ & $138.2 \pm 10.6$ & $164.3 \pm 15.5$ & $168.4 \pm 10.9$ \\
TCS & $305.8 \pm 38.8$ & $385.7 \pm 72.9$ & $387.9 \pm 60.9$ & $487.3 \pm 63.0$ & $337.4 \pm 49.9$ \\
$\mathrm{CO}_{2}$ seq. & $1129.5 \pm 142.2$ & $1407.5 \pm 267.8$ & $1431.3 \pm 223.5$ & $1799.1 \pm 231.1$ & $1246.1 \pm 187.7$ \\
\hline
\end{tabular}

$A G B$ aboveground biomass, $B B$ belowground biomass, $S O C$ soil organic carbon $(0-30 \mathrm{~cm}), T C S$ total carbon stocks 
A

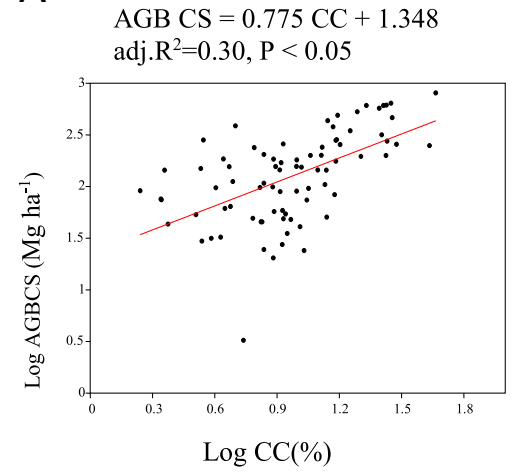

C

AGB CS $=-0.08106 \mathrm{DBH}^{2}+2.668 \mathrm{DBH}-2.839$ adj. $\mathrm{R}^{2}=0.98 ; \mathrm{P}<0.05$

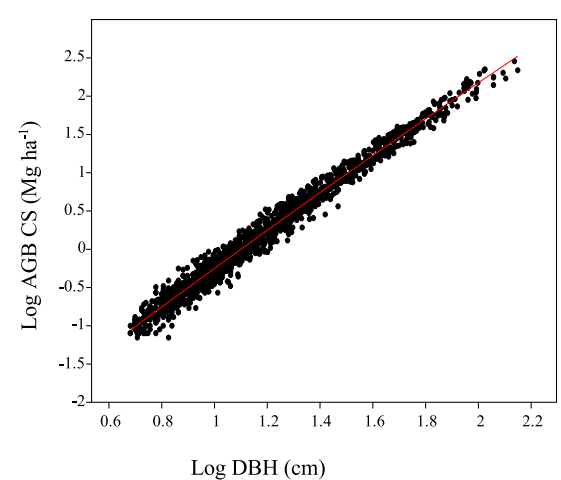

B $\quad$ AGB CS $=1.251 \mathrm{BA}+2.103$

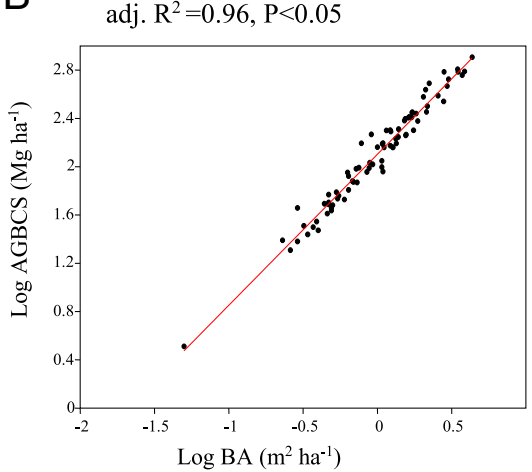

D

AGB CS $=4.953 \mathrm{H}^{2}-6.032 \mathrm{H}+1.135$ adj. $\mathrm{R}^{2}=0.79, \mathrm{P}<0.05$

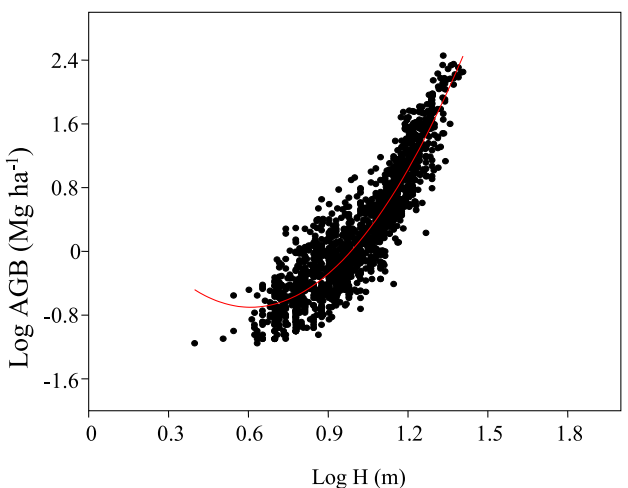

Fig. 5 Allometric regression between the log-transformed diameter (DBH), total height $(\mathrm{H})$, and AGB CS (each dot and lines correspond to the observed and fitted values, respectively)

middle elevation $\left(188.4 \pm 38.4 \mathrm{Mg} \mathrm{C}\right.$ ha $\left.^{-1}\right)$, respectively, and the difference was statistically significant $(F=4.63, P<0.05)$. In terms of the slope gradient, the mean AGB $C$ stock was the lowest on flat areas $\left(113.7 \pm 31.3 \mathrm{Mg} \mathrm{C} \mathrm{ha}{ }^{-1}\right)$ and the highest on steep slopes $\left(253.5 \pm 37.8 \mathrm{MgC} \mathrm{ha}{ }^{-1}\right)$, and the difference was statistically significant $(F=5.846, P<0.05)$. Similarly, the mean AGB C and SOC stocks were the lowest at the northern $\left(75.0 \pm 16.8 \mathrm{Mg} \mathrm{C} \mathrm{ha}^{-1}\right)$ and highest at the southern $\left(272.9 \pm 43.8 \mathrm{Mg} \mathrm{Cha}^{-1}\right)$ aspects. The southern

Table 6 Pearson correlation matrix between carbon stocks and site factors

\begin{tabular}{|c|c|c|c|c|c|c|c|c|c|c|}
\hline Parameter & AGB CS & $\mathrm{SOC} s$ & TN S & $\mathrm{CC}$ & $\mathrm{pH}$ & SOC & $\mathrm{TN}$ & Canopy & Elv & Slp \\
\hline \multicolumn{11}{|l|}{$\overline{A G B}$ CS(Mg ha $\left.{ }^{-1}\right)$} \\
\hline SOC s $\left(\mathrm{Mg} \mathrm{ha}^{-1}\right)$ & 0.29 & & & & & & & & & \\
\hline TN s $\left(\mathrm{Mg} \mathrm{ha}^{-1}\right)$ & 0.38 & 0.83 & & & & & & & & \\
\hline CC (\%) & 0.71 & 0.45 & 0.48 & & & & & & & \\
\hline Soil pH & -0.17 & -0.34 & -0.37 & -0.14 & & & & & & \\
\hline SOC (\%) & 0.28 & 0.91 & 0.72 & 0.37 & -0.48 & & & & & \\
\hline TN (\%) & 0.26 & 0.81 & 0.77 & 0.37 & -0.51 & 0.88 & & & & \\
\hline Canopy (\%) & -0.15 & -0.14 & -0.02 & -0.12 & 0.09 & -0.14 & -0.08 & & & \\
\hline Elevation (m) & 0.08 & 0.37 & 0.30 & 0.12 & -0.63 & 0.53 & 0.46 & -0.10 & & \\
\hline Slope (\%) & 0.25 & 0.07 & 0.14 & 0.28 & -0.01 & 0.01 & 0.03 & -0.13 & -0.06 & \\
\hline
\end{tabular}

AGB CS aboveground biomass carbon stocks, SOC s soil organic carbon stock, TN $s$ total nitrogen stock, CC canopy cover, Canopy canopy openness, Elv elevation, Slp slope. Soil properties and carbon stocks $(0-30 \mathrm{~cm})$. Data in italics are significant at $\mathrm{P}<0.05$ 


\section{A}

AGB CS $=-0.00015$ Elv $^{2}+6.903 E l v-7564$

adj. $\mathrm{R}^{2}=0.04, \mathrm{P}>0.05$

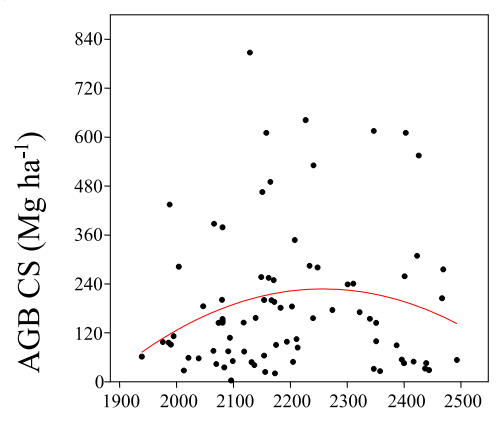

Elevation (m)

C

SOC Stock $=-32.89 \mathrm{pH}^{2}+349.2 \mathrm{pH}-840.1$ adj. $\mathrm{R}^{2}=0.11, \mathrm{P}<0.05$

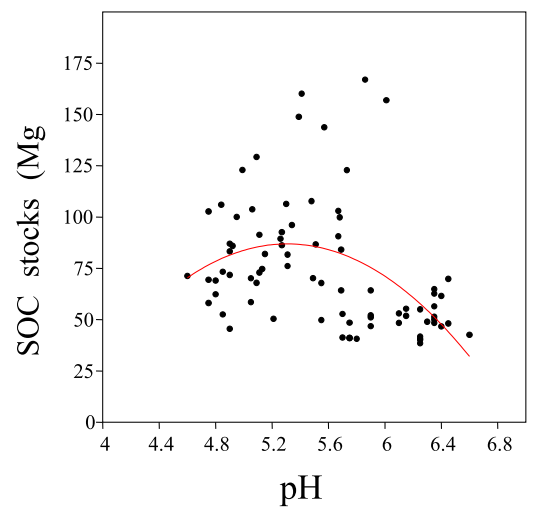

B

SOC Stock $=0.07781$ Elv-96.46

adj. $\mathrm{R}^{2}=0.12, \mathrm{P}<0.05$

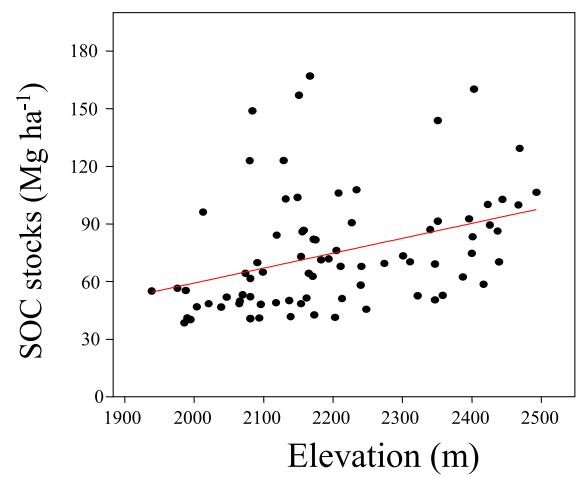

D

$\mathrm{TN}$ stocks $=-4.608 \mathrm{pH}^{2}+48.71 \mathrm{pH}-119.6$ adj. $\mathrm{R}^{2}=0.13, \mathrm{P}<0.05$

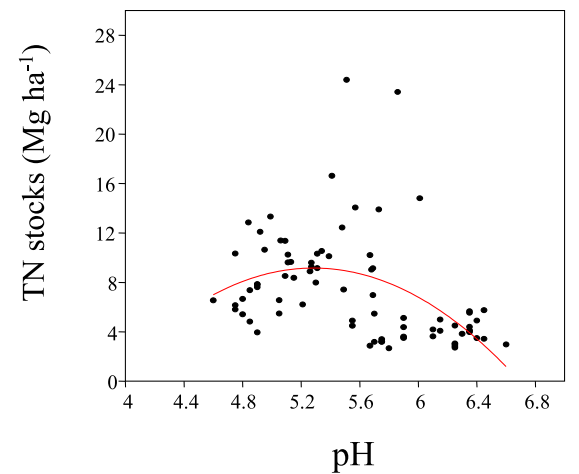

Fig. 6 Relation between carbon and total nitrogen stocks $(0-30 \mathrm{~cm})\left(\mathrm{Mg} \mathrm{ha}^{-1}\right)$ in response to elevation and soil pH. Elv, elevation (each dot and line correspond to observed and fitted values, respectively). AGB CS, aboveground biomass carbon stock

and western aspects $(n=26)$ contained considerable amounts of AGB CS, which were significantly $(P<0.05)$ different $(F=7.344, P<0.05)$. The mean SOC stock was the lowest at the western $\left(124.9 \pm 10.1 \mathrm{Mg} \mathrm{C} \mathrm{ha}^{-1}\right)$ and the highest at both the southern $\left(171.8 \pm 11.9 \mathrm{Mg} \mathrm{C} \mathrm{ha}^{-1}\right)$ and eastern $\left(218.5 \pm 115.6 \mathrm{Mg} \mathrm{C}^{-1}\right)$ aspects. The results revealed the significant variation of SOC stocks between the western and southern aspects $(F=8.97, P<0.05)$.

\section{Aboveground carbon stocks along with an anthropogenic disturbance gradient}

The result revealed that AGB CS attained negative quadratic pattern along the disturbance index, particularly the illegal harvesting of woody species (adj. $R^{2}=0.04$, $P<0.05$ ) at $P<0.05$ (Fig. 7). The log-transformed values of the disturbance index (0.8 to $1.6 \%$ ) favored the storage of biomass carbons. However, the AGB CS of forests were reduced more below and above this range of disturbance index. This clearly demonstrates that illegal biomass extraction could affect stand structure and increase carbon emission. Thus, it requires regular monitoring and management to improve AGB CS of forests.

\section{Discussion}

Comparison of carbon stocks of forests with other studies The results from the present study of biomass and carbon stocks revealed the relevant remnant forests for climate mitigation. The AGB CS ranging from 140 to $268 \mathrm{Mg} \mathrm{C} \mathrm{ha}{ }^{-1}$ in the studied forests are comparable with the carbon stocks of the protected dry Afromontane forests of Ethiopia (107 to $285 \mathrm{Mg} \mathrm{C} \mathrm{ha}^{-1}$ ) (Moges et al. 2010; Sahle 2011; Simegn and Soromessa 2015; Yohannes et al. 2015) and the other tropical montane forests (271 Mg C ha ${ }^{-1}$ ) of Ecuador (Spracklen and Righelato 2014). The AGB CS in the least-disturbed Bari forest were higher than that from a mature forest of Costa 
Table 7 Tukey's pairwise analysis of mean carbon stock $\left(\mathrm{Mg} \mathrm{ha}^{-1}\right)$ in topographical categories

\begin{tabular}{|c|c|c|}
\hline Categories & AGB CS $\left(\mathrm{Mg} \mathrm{ha}^{-1}\right)$ & SOC stock $\left(\mathrm{Mg} \mathrm{ha}^{-1}\right)$ \\
\hline \multicolumn{3}{|l|}{ Elevation (m) } \\
\hline Lower $(N=25),(1900-2100)$ & $138.1 \pm 23.3^{a}$ & $118.6 \pm 10.5^{a}$ \\
\hline Middle $(N=32),(2100-2300)$ & $234.7 \pm 35.1^{b}$ & $155.1 \pm 10.9^{b}$ \\
\hline Higher $(N=23),(2300-2500)$ & $188.4 \pm 38.4^{\mathrm{a}}$ & $174.6 \pm 11.8^{b}$ \\
\hline \multicolumn{3}{|l|}{ Slope (\%) } \\
\hline Flat $(N=16),<10$ & $113.7 \pm 31.3^{b}$ & $137.4 \pm 10.9^{b}$ \\
\hline Intermediate $(N=32), 10-20$ & $167.8 \pm 23.3^{\mathrm{a}}$ & $140.8 \pm 10.9^{b}$ \\
\hline Steep $(N=32),>20$ & $253.5 \pm 37.8^{\mathrm{a}}$ & $163.8 \pm 11.7^{\mathrm{a}}$ \\
\hline \multicolumn{3}{|l|}{ Aspect } \\
\hline$E(N=2)$ & $227.4 \pm 27.4$ & $218.5 \pm 115.6$ \\
\hline$N(N=8)$ & $75.0 \pm 16.8$ & $136.4 \pm 14.2$ \\
\hline $\mathrm{NE}(N=4)$ & $262.0 \pm 101.7$ & $149.7 \pm 37.9$ \\
\hline NW $(N=4)$ & $176.3 \pm 59.2$ & $148.3 \pm 24.1$ \\
\hline $\mathrm{S}(N=26)$ & $272.9 \pm 43.8^{a}$ & $171.8 \pm 11.9^{a}$ \\
\hline $\operatorname{SW}(N=10)$ & $193.5 \pm 36.7$ & $152.2 \pm 21.8$ \\
\hline$W(N=26)$ & $133.1 \pm 27.3^{b}$ & $124.9 \pm 10.1^{b}$ \\
\hline
\end{tabular}

$N$ is the number of sample quadrats. $E$ east, $N$ north, $N E$ northeast, $N W$ northwest, $S$ south, $S W$ southwest, $W$ west. Different letters in vertical refer to significant difference at $P<0.05$ )

Rica (219.4 Mg C ha ${ }^{-1}$ ) (Tanner et al. 2016). The AGB CS in intermediately disturbed forests (170 to $207 \mathrm{Mg} \mathrm{C} \mathrm{ha}^{-1}$ ) were slightly higher than carbon stocks of the montane forest of Tanzania (ranging $166 \mathrm{Mg} \mathrm{C} \mathrm{ha}^{-1}$ ) (Willcock et al. 2014). By contrast, the AGB C stock values in the highly disturbed Kahatsa forest $\left(140 \mathrm{Mg} \mathrm{C} \mathrm{ha}^{-1}\right)$ was found to be lower than a montane forest of Tanzania $\left(166 \mathrm{Mg} \mathrm{C} \mathrm{ha}^{-1}\right)$ (Willcock et al. 2014) but higher than a montane forest of

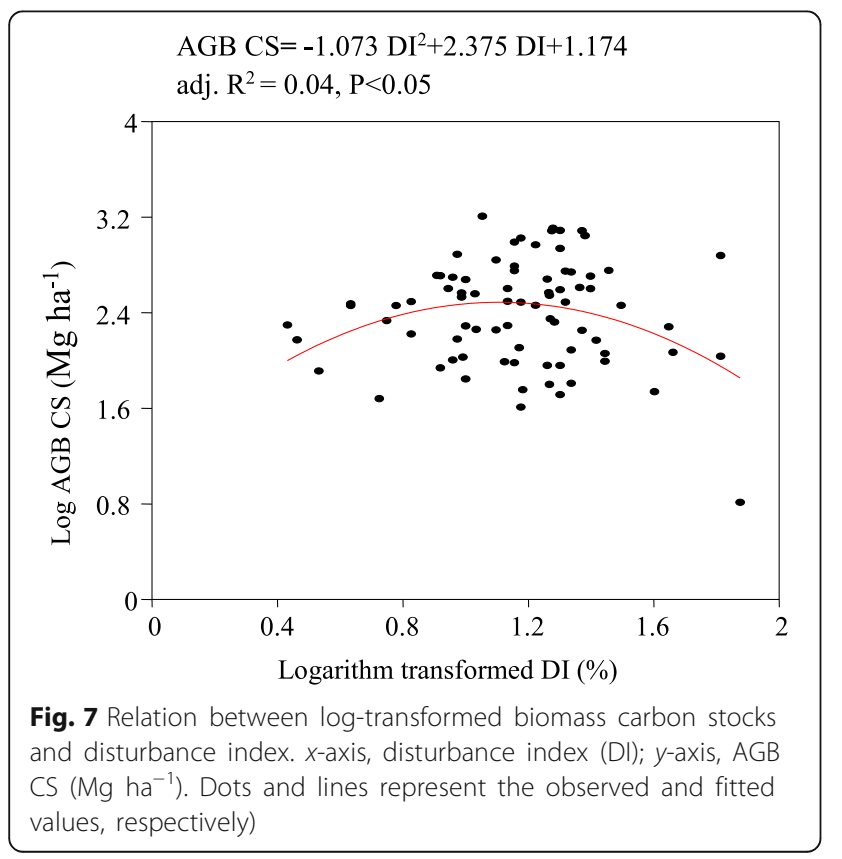

Colombia (111.6 Mg C ha ${ }^{-1}$ ) (Sierra et al. 2007). The present result pointed out that the Bari forest was facing relatively low disturbance over a period that shows in large biomass and carbon stocks than other forests. Furthermore, the mean of AGB CS $\left(191.6 \mathrm{Mg} \mathrm{C} \mathrm{ha}{ }^{-1}\right)$ from all forests was found to be higher than a lowland tropical forest of West Africa (161.4 $\mathrm{t} \mathrm{Mg} \mathrm{C} \mathrm{ha}{ }^{-1}$ ) (Lindsell and Klop 2013) and tropical dry forest of India (184.2 $\mathrm{Mg} \mathrm{C} \mathrm{ha}^{-1}$ ) (Srinivas and Sundarapandian 2018). However, it tended to be lower than a mature forest of Costa Rica (219.4 Mg C ha-1) (Tanner et al. 2016). This demonstrated that the degree of disturbances and topographic factors in the forests causes variations of carbon storage in local, regional, and country levels.

The soil organic carbon (SOC) and total nitrogen (TN) varied among forests. In all forests, the bulk density, soil $\mathrm{pH}, \mathrm{SOC}$, and TN content varied with the soil depth. The soil bulk density and $\mathrm{pH}$ gradually increase along with increasing depth, but the SOC and TN concentrations decreased with respect to soil depth. This implied that the organic matter present on the topsoil $(0-15 \mathrm{~cm})$ was more as compared to the subsoil layer $(15-30 \mathrm{~cm})$. Similar to the present investigation, recent studies also reported that soil bulk density increased while organic carbon and nitrogen decreased with increasing depth in the forests (Ouyang et al. 2018) as well as agricultural soils (Gebeyehu and Soromessa 2018). The soil bulk density of studied forests (ranged from 0.61 to $0.79 \mathrm{~g} \mathrm{~cm}^{-3}$ on the topsoil and 0.76 to $0.97 \mathrm{~g} \mathrm{~cm}^{-3}$ on the subsoil layer) was lower, reflecting common features for 
montane forest compared to the other studied forests (Bangroo et al. 2017). Soil pH is slightly acidic in nature (pH ranged from 5.04 to 5.96 and 5.05 to 6.08 on the topsoil and subsoil layers, respectively) with a similar trend to other studies (Bangroo et al. 2017). An early study explained that soil $\mathrm{pH}$ below 5 would slow down humification, which would affect soil $\mathrm{C}$ sequestration (Amonette et al. 2004), but when soil pH is in the 6 to 7 range, soil phosphorous availability is the greatest for most forests (Nyakatawa et al. 2012). Therefore, the soil pH found in this study is generally ranging below 6 , so the forest soil contained a low amount of phosphorous, and $\mathrm{pH}$ would potentially affect soil carbon stocks. The relation between carbon stocks and $\mathrm{pH}$ had exhibited quadratic, indicating that the moderate soil $\mathrm{pH}$ enhanced the increase of carbon and total nitrogen stocks of forests but an increase or decrease in this range would affect SOC and TN concentrations. Therefore, changes in a small portion of SOC and TN storage can influence atmospheric carbon dioxide concentrations, and they are very important indicators of soil fertility and productivity as suggested in other studies (Jiménez et al. 2011).

An early study suggested that the $\mathrm{C} / \mathrm{N}$ ratio has also been widely used as an index of the quality of organic matter. Soils with the C-to- $\mathrm{N}$ ratio in the range of 10 to 12 require an excess of microbial activities and contribute to slow organic matter decomposition (Landon 1991). Similar to this study, C/N ratio in the four studied forests was below 12, suggesting slow organic matter decomposition. Specifically, the value of $\mathrm{C} / \mathrm{N}$ ratio in the Bari forest remains low comparing to others due to better availability of both SOC and TN content and moderate level of soil $\mathrm{pH}$. These soil properties in the Bari forest were enhanced to have better soil fertility and slow organic matter decaying than other forests that it agrees with other findings on oak forests of Iran (Eshaghi et al. 2018). In contrast, $\mathrm{C} / \mathrm{N}$ ratio in the Tsahare Kan forest was found exceeding 12, indicating higher rates of organic carbon decomposition and emission of carbon dioxide than the other forests. Therefore, the remarkable variations of soil properties that represent soil fertility can have great influences on the ecosystem stability and carbon storage of forests.

In general, SOC and TN stocks decreased with depth, reflecting greater than $50 \%$ of stocks found on the topsoil layers in agreement with other studies (Bangroo et al. 2017). This reflects that the conversion of forest vegetations to grazing and cultivation land contributes the highest amount of $\mathrm{CO}_{2}$ emission to the atmosphere. The mean SOC stocks of $0-30 \mathrm{~cm}$ soil depth under the 5 forests $\left(149.32 \mathrm{Mg} \mathrm{C} \mathrm{ha}{ }^{-1}\right.$ ) were found to be higher than the previously quantified carbon stocks in tropical forests (121 to $123 \mathrm{Mg} \mathrm{C} \mathrm{ha}^{-1}$ ) (Lal 2004), forest of Colombia (96 Mg C ha ${ }^{-1}$ ) (Sierra et al. 2007), and
Singapore (110 Mg C ha ${ }^{-1}$ ) (Ngo et al. 2013). However, SOC stocks at 5 forests were found to be lower than the SOC stocks of the Humbo forest of Ethiopia (168 $\mathrm{Mg} \mathrm{C} \mathrm{ha}^{-1}$ ) (Chinasho et al. 2015) and Hawaiian tropical montane forests (ranging from 194 to $288 \mathrm{Mg} \mathrm{C} \mathrm{ha}^{-1}$ ) (Selmants et al. 2014). The nitrogen stocks up to $30 \mathrm{~cm}$ ranged between 8.14 and $17.77 \mathrm{MgC} \mathrm{ha}^{-1}$ at the 5 forests. This demonstrates that the climatic condition among tropical forests and disturbance level in local (present study) would be the primary source of variations of carbon and total nitrogen of forests.

The total biomass and soil carbon stocks at 5 forests accounted for ranging from 305.3 to $487.8 \mathrm{Mg} \mathrm{C} \mathrm{ha}^{-1}$ (mean of $340.92 \mathrm{Mg} \mathrm{C} \mathrm{ha}^{-1}$ ) were comparable to some protected forests of Ethiopia and other tropical forests of Singapore (337 Mg C ha ${ }^{-1}$ ) (Ngo et al. 2013). In Ethiopia, the total biomass and soil carbon stocks recorded in the 5 studied forests were lower than the sum of biomass and soil carbon stocks (507 Mg C ha ${ }^{-1}$ ) reported from Adaba-Dodola community forest (Bazezew et al. 2015), but higher than the carbon stocks recorded in the Humbo forest (213.43 $\mathrm{Mg} \mathrm{C} \mathrm{ha}{ }^{-1}$ ) (Chinasho et al. 2015). The observed differences of carbon stocks between forests occurred primarily due to variations of elevation, slope, aspect, disturbances, and management level.

\section{Enhancement of stand structure on biomass carbon storage}

The relation between stem density and AGB CS showed that the smaller size classes held most of the stems, but contributed to a small fraction of the live AGB CS. This suggests that the size of tree species explained more of the observed variation of AGB CS than stem density. The basal cover of adult trees showed a significant positive relationship with AGB CS, reflecting that different size responds differently and develops different adaption mechanisms to resist disturbances and environmental stress. This result agrees with previous studies that showed a positive relationship between carbon stocks and basal cover (Bohn and Huth 2017; Vilanova et al. 2018). Increasing height and stem diameter of species played a positive role in increasing biomass and carbons stocks similar to the results reported from a previous study (Rubin et al. 2006). Canopy cover also showed a positive association with AGB CS. Multilayered individual species exhibited higher efficiency to capture and use light (Yachi and Loreau 2007) and, thus, a particular capacity for carbon storage and sequestration. The multilayered canopy cover makes the largest contribution to forest biomass and carbon stocks.

Variation in AGB CS across the studied forests was, therefore, a function of stem diameter, height, and canopy cover of trees. This explains why large tree size and stand basal cover are better predictors of AGB CS than 
the overall tree density. Regarding the potential of tree species to store carbon stocks, the result of the study showed that dominant species stored more than $58 \%$ of carbon stocks in all the forests. Similarly, many studies reported that dominant species played a major role in terms of carbon storage in the forests (Winfree et al. 2015; Padmakumar et al. 2018; McNicol et al. 2018).

\section{Effect of topographic elevation, slope, and aspect on carbon stocks}

Topography, in terms of elevation, slope, and aspects, has resulted in significant variations on carbon stocks of forests. For instance, biomass and soil carbon stocks in the middle elevations tended to be higher than the lower elevations of forests, which is associated with higher disturbances observed at the lower elevations. Similarly, biomass and soil carbon stock of intermediate and steep topographic slopes tended to be higher than flat slope due to higher biomass extraction in the flat slope of forests. Therefore, biomass extraction from tree species was the major factor responsible for the reduction of biomass and carbon stocks without a change in forest area. This indicated that deforestation and forest degradation because of the removal of large-sized tree species would contribute to the highest emission of carbon to the atmosphere. Hence, proper conservation and management of large-sized tree species would lead to reduction strategies of carbon emissions. Although AGB CS decreased with increasing elevation, SOC stocks increased as elevation increased. This showed that increasing elevation might increase soil moisture that plays a major role in increasing the SOC stocks in the higher elevations, which is consistent with the findings from other studies (Unger et al. 2010; Hoffmann et al. 2014).

The correlation and regression analyses indicated that AGB and soil carbon stocks have significant positive linear relationships with elevation. This finding concurs with those of the previous study that reported positive linear relationships between carbon storage and elevation (Sharma et al. 2010). In contrast, other authors reported that AGB carbon stocks declined with increasing elevation (Moser et al. 2011) and showed a unimodal pattern (Ensslin et al. 2015) or no linear relationship (Simon et al. 2018). The increase in elevation played a positive linear relationship with SOC stocks in the present study due to higher moisture content and lower temperature at higher elevation. This result agrees with those from previous studies, which demonstrated that the SOC stocks increased slightly with increased elevation (Hoffmann et al. 2014) and low temperature (Selmants et al. 2014). Lower temperatures slow rates of organic matter decomposition since decompositions of organic matter activities by microbes are slower at cooler temperatures, thereby facilitating the accumulation of thicker litter layers and higher soil organic matter. These conditions lead to low $\mathrm{CO}_{2}$ emission from the soil and thus contribute to the storage of higher SOC stocks.

Topographic slope showed a positive correlation with carbon stocks. Slopes are supposed to force distribution patterns of tree species (McEwan and Muller 2006) and influence aboveground biomass (Valencia et al. 2009). When the degree of slope increased in the studied forests, grazing intensity declined due to inaccessibility for grazing activities. Also, increasing slope gradient could be expected to partly explain the spatial pattern of carbon stocks because wood harvesting is more likely to occur at lower elevations and gentle slopes, which are more accessible and more attractive to agriculture. Hence, the slope has a positive role in increasing SOC and TN stocks on steep slopes. Carbon stocks varied with topographic aspects. The highest SOC stock values were observed along the southern aspects compared with northern aspect since altitude affects mountain vegetation by directly influencing the solar radiation and soil moisture. In addition, the southern aspect favored the growth of different plants, and the sites could not be accessible for agricultural and grazing activities due to steep slopes.

\section{Effect of harvesting on carbon stocks of forests}

Deforestation, largely the conversion of forestland into agricultural land, has remained the major negative force in tropical forest cover and services. The results of this study revealed that selective harvesting has shown a significant effect on biomass and carbon stocks. The severity and intensity of disturbances tended to decrease carbon storage and related strongly to the amount of carbon reduction. This implied that selective harvesting targeting large trees would result in a reduction of carbon stocks. This finding concurs with the results from other studies, which reported that the extractions of large trees led to the reduction of AGB CS in the forests (Lindsell and Klop 2013) and forest landscape (Meyer et al. 2018). As a result, the finding from the present study confirmed that selective harvesting is a major cause of forest degradation in the studied forests.

The results also revealed that the removal of woody species does not only affect aboveground biomass but also SOC and TN carbon stocks. Thus, selective harvesting can cause soil compaction, increased bulk density, and decreased porosity. A similar study reported that harvesting of woody species has increased in frequency and extent of forest degradation (Norris et al. 2010). The reduction of SOC stock might be due to shifts in the abundance of large-sized woody and herbaceous vegetation that, in turn, resulted in a decrease in productivity (Jackson et al. 2000). 
Correlation analysis showed that forest canopy openness had correlated negativity with SOC and TN stocks. This implies that increasing of canopy openness exhibited a considerable reduction of SOC and TN stocks in the studied forests. This was because of forest canopy openness, created mainly by selective harvesting or windthrow of large canopy species. Removal of canopy species would result in the reduction of biomass and formation of organic matter. This, in turn, decreases decomposition rates of the surface litter because of the reduction in biotic activity and decline in the soil moisture content. A similar study also reported that the extractions of large trees resulted in the reduction of carbon stocks in the forests (Lindsell and Klop 2013) and forest landscape (Meyer et al. 2018). The harvesting and other natural disturbances of forests caused a change in canopy cover, thereby facilitating soil erosion, which affects SOC at the surface layer.

\section{Forest carbon sequestration and implication of climate change mitigation}

Tree growth may reduce the greenhouse effect due to tree assimilation of $\mathrm{CO}_{2}$ during photosynthesis. The potential of forests to sequester carbon depends on the disturbance level, management, and size class of trees. This suggested that information about aboveground biomass (AGB) and carbon stocks is necessary for estimating and forecasting ecosystem productivity, global $\mathrm{C}$ cycle, and carbon budgets. The previous study estimated that a reduction in the global forest area decreased forest biomass carbon stocks by $0.5 \mathrm{Gt}$ annually during the period 2005-2010 (FAO 2010). Thus, the reductions of deforestation and degradation and an increase in the forest cover have been a common feature of the mitigation of climate change. However, our result confirmed that only expanding forest area might not be sufficiently enough to improve the mitigation potential of forests rather than requiring sustainable management of existing forests. The reduction in the extraction of large trees and enrichment of planting on degraded forests have been suggested as a gainful and environmentally beneficial strategy for management options for carbon sequestration. Currently, in five forest stands, the mean of $1402.7 \mathrm{t}$ of $\mathrm{CO}_{2}$ sequestered in the biomass and soils. Therefore, the release of $\mathrm{CO}_{2}$ to the atmosphere can be avoided, enhancing the sequestration of carbon in forests. This would also be enhanced by appropriate allocation of carbon budget for local communities to improve protection, conservation, and sustainable forest management.

\section{Conclusions}

The aboveground biomass and soil carbon stocks of the studied five forests were comparable to those of protected forests. The biomass and soil carbon pool sequestered a substantial amount of carbon dioxide in the forests. The dominant and large-sized tree species stored the largest amount of forest carbon. The stem diameter, total height, and canopy cover of the tree species explained the large variation of AGB stocks. Topographic and disturbance variations exhibited a significant difference on biomass carbon, soil carbon, and nitrogen stocks. Soil carbon stocks varied along the vertical and horizontal distribution, suggesting that conservation of topsoil and forests is fundamental. Intermediate levels of disturbance resulted in increased AGB carbon stocks, but either low or high levels of disturbance led to the reduction of AGB carbon stocks. Moderate levels of soil $\mathrm{pH}$ exhibited a positive role in soil carbon storage, but either low or high levels of soil $\mathrm{pH}$ caused a reduction in soil carbon and nitrogen stocks. As a result, the conservation and management of forests could improve stand structures of tree species and thus increase biomass and soil organic matter, making the forests as a potential means for mitigation of climate change. Biomass extraction contributes not only to the change of species compositions but also to the reduction of stand structure and carbon stocks. This needs intensive monitoring and management to improve the sequestration potential of forests.

\section{Additional file}

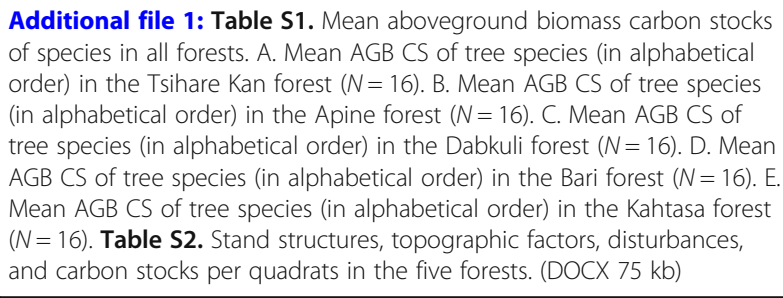

\section{Acknowledgments}

We are grateful to Addis Ababa University (AAU) and Ethiopian Environment and Forestry Research Institute (EERIE) for financial support. Specifically, many thanks go to Water Works Design and Supervision Enterprise (WWDSE) for allowing soil laboratory analysis in Addis Ababa. Finally, we are thankful to the three anonymous reviewers for their valuable comments on an earlier version of the manuscript.

\section{Funding}

The research is supported by the small research thematic grant of Addis Ababa University (AAU) and Ethiopian Environment and Forestry Research Institute.

\section{Availability of data and materials}

The data can be available in Additional files and for detail upon request to the Corresponding Author.

\section{Authors' contributions}

GG conceived and designed the research method, data collection, and laboratory analysis; wrote the manuscript; and conducted the analyses. TS contributed significant input into the manuscript by supervising the study. TB designed the research method and supported the data collection. DT provided significant input through many reviews on the manuscript preparation. All authors read and approved the manuscript. 


\section{Ethics approval and consent to participate}

Not applicable.

\section{Consent for publication}

Not applicable.

\section{Competing interests}

The authors declare that they have no competing interests.

\section{Publisher's Note}

Springer Nature remains neutral with regard to jurisdictional claims in published maps and institutional affiliations.

\section{Author details}

${ }^{1}$ Center for Environmental Science, Addis Ababa University, Addis Ababa, Ethiopia. ${ }^{2}$ Ethiopian Environment and Forestry Research Institute, Addis Ababa, Ethiopia. ${ }^{3}$ Department of Crop Science and Production, Botswana University of Agriculture and Natural Resources, Gaborone, Botswana.

Received: 19 November 2018 Accepted: 25 February 2019

Published online: 19 March 2019

\section{References}

Aerts R, Van Overtveld K, November E, Wassie A, Abiyu A, Demissew S, Daye DD, Giday K, Haile M, TewoldeBerhan S. Conservation of the Ethiopian church forests: threats, opportunities, and implications for their management. Sci Total Environ. 2016:551:404-14.

Amonette JE, Kim J, Russell CK. Enhancement of soil carbon sequestration: a catalytic approach. Am Chem Soc Div Fuel Chem. 2004;49:366.

Bangroo S, Najar G, Rasool A. Effect of altitude and aspect on soil organic carbon and nitrogen stocks in the Himalayan Mawer forest range. Catena. 2017;158:63-8.

Bazezew MN, Soromessa T, Bayable E. Above-and below-ground reserved carbon in Danaba community forest of Oromia region, Ethiopia: implications for $\mathrm{CO}_{2}$ emission balance. Am J Environ Prot. 2015:4:75-82.

Bohn FJ, Huth A. The importance of forest structure to biodiversity-productivity relationships. R Soc Open Sci. 2017:4:05-21.

Chave J, Réjou-Méchain M, Búrquez A, Chidumayo E, Colgan MS, Delitti WB, Duque A, Eid T, Fearnside PM, Goodman RC. Improved allometric models to estimate the aboveground biomass of tropical trees. Glob Chang Biol. 2014;20:3177-90.

Chen J, John R, Sun G, McNulty S, Noormets A, Xiao J, Turner MG, Franklin JF. Carbon fluxes and storage in forests and landscapes. In: Azevedo J.C. et al. (eds.), Forest Landsc Glob Chang: Springer Science+Business Media New York 2014. p. 139-66. https://doi.org/10.1007/978-1-4939-0953-7_6.

Chinasho A, Soromessa T, Bayable E. Carbon stock in woody plants of Humbo forest and its variation along altitudinal gradients: the case of the thumb district, Wolaita Zone, southern Ethiopia. Int J Environ Prot Policy. 2015;3:97-103.

Ensslin A, Rutten G, Pommer U, Zimmermann R, Hemp A, Fischer M. Effects of elevation and land use on the biomass of trees, shrubs, and herbs at Mount Kilimanjaro. Ecosphere. 2015;6:1-15.

Eshaghi RJ, Gelare V, Osman S, Hosein M. Effects of anthropogenic disturbance on plant composition, plant diversity and soil properties in oak forests, Iran. J Forest Science. 2018;64:358-70.

FAO. Global Forest Resources Assessment. Main report, FAO Forest paper 163. 2010.

Gautam TP, Mandal TN. Effect of disturbance on biomass, production and carbon dynamics in the moist tropical forest of eastern Nepal. Forest Ecosystems. 2016;3(1):11.

Gebeyehu G, Soromessa T. Status of soil organic carbon and nitrogen stocks in Koga Watershed Area, Northwest Ethiopia. Agri Food Security. 2018;7:9.

Goetz SJ, Hansen M, Houghton RA, Walker W, Laporte N, Busch J. Measurement and monitoring needs, capabilities and potential for addressing reduced emissions from deforestation and forest degradation under REDD+. Environ Res Lett. 2015;10:123001.

Harris NL, Brown S, Hagen SC, Saatchi SS, Petrova S, Salas W, Hansen MC, Potapov PV, Lotsch A. Baseline map of carbon emissions from deforestation in tropical regions. Science. 2012;336:1573-6.
Hoffmann U, Hoffmann T, Johnson EA, Kuhn NJ. Assessment of variability and uncertainty of soil organic carbon in a mountainous boreal forest (Canadian Rocky Mountains, Alberta). Catena. 2014;113:107-21.

Hosonuma N, Herold M, De Sy V, De Fries RS, Brockhaus M, Verchot L, Angelsen A, Romijn E. An assessment of deforestation and forest degradation drivers in developing countries. Environ Res Lett. 2012;7:044009.

Houghton R. Aboveground forest biomass and the global carbon balance. Glob Chang Biol. 2005;11:945-58.

Hunter M, Keller M, Victoria D, Morton D. Tree height and tropical forest biomass estimation. Biogeosciences. 2013;10:8385-99.

Husch B, Beers T, Kershaw JR. Forest mensuration. 4th ed. New York: Wiley; 2003.

IPCC. IPCC guidelines for national greenhouse gas inventories. Intergovernmental panel on climate change. 2006.

Jackson RB, Schenk H, Jobbagy E, Canadell J, Colello G, Dickinson R, Field C, Friedlingstein $\mathrm{P}$, Heimann $\mathrm{M}$, Hibbard K. Belowground consequences of vegetation change and their treatment in models. Ecol Appl. 2000;10:470-83.

Jiménez JJ, Lorenz K, Lal R. Organic carbon and nitrogen in soil particle-size aggregates under dry tropical forests from Guanacaste, Costa Rica-implications for within-site soil organic carbon stabilization. Catena. 2011;86:178-91.

Kelbessa E, Demissew S. Diversity of vascular plant taxa of the flora of Ethiopia and Eritrea. Ethiop J Biol Sci. 2014;13:37-45.

Kent M. Vegetation description and data analysis: a practical approach. 2nd ed. John Wiley \& Sons; 2011.

Lal R. Soil carbon sequestration to mitigate climate change. Geoderma. 2004;123:1-22

Landon J. Booker agriculture international limited. Booker tropical soil manual: a handbook for soil survey and agricultural land evaluation in the tropics and subtropics. New York: Routledge; 1991.

Lee J, Hopmans JW, Rolston DE, Baer SG, Six J. Determining soil carbon stock changes: simple bulk density corrections fail. Agri Ecosys Environ. 2009;134:251-6.

Lemenih M, Karltun E, Olsson M. Soil organic matter dynamics after deforestation along a farm field chronosequence in southern highlands of Ethiopia. Agri Ecosys Environ. 2005;109:9-19.

Lindsell JA, Klop E. Spatial and temporal variation of carbon stocks in a lowland tropical forest in West Africa. Forest Ecol Manag. 2013;289:10-7.

McEwan RW, Muller RN. Spatial and temporal dynamics in canopy dominance of an old-growth central Appalachian forest. Can J For Res. 2006;36:1536-50.

Mcnicol IM, Ryan CM, Dexter KG, Ball SM, Williams M. Aboveground Carbon Storage and Its Links to Stand Structure, Tree Diversity and Floristic Composition in South-Eastern Tanzania. Ecosystems. 2018; 21:740-754.

Mengistu T, Teketay D, Hulten $H$, Yemshaw $Y$. The role of enclosures in the recovery of woody vegetation in degraded dryland hillsides of central and northern Ethiopia. J Arid Environ. 2005:60:259-81.

Meyer V, Saatchi S, Clarck D, Keller M, Vicent G, Ferraz A, Espírito-Santo F, Oliveira MD, Kaki D, Chave J. Canopy area of large trees explains aboveground biomass variations across neotropical forest landscapes. Embrapa Acre-Artigo em periódico indexado (ALICE); 2018.

Moges Y, Eshetu Z, Nune S. Ethiopian forest resources: current status and future management options in view of access to carbon finances. Ethiopian Climate Research and Networking and United Nations Development. Addis Ababa; 2010.

Moser G, Leuschner C, Hertel D, Graefe S, Soethe N, Lost S. Elevation effects on the carbon budget of tropical mountain forests ( $S$ Ecuador): the role of the belowground compartment. Glob Chang Biol. 2011;17:2211-26.

Nelson DW, Sommers LE. Total carbon, organic carbon, and organic matter. Methods of soil analysis part 3-chemical methods; 1996. p. 961-1010.

Ngo KM, Turner BL, Muller-Landau HC, Davies SJ, Larjavaara M, bin Nik Hassan NF, Lum S. Carbon stocks in primary and secondary tropical forests in Singapore. Forest Ecol Manag. 2013;296:81-9.

Norris K, Asase A, Collen B, Gockowksi J, Mason J, Phalan B, Wade A. Biodiversity in a forest-agriculture mosaic-the changing face of West African rainforests. Biol Conserv. 2010;143:2341-50.

Nyakatawa EZ, Mays DA, Naka K, Bukenya JO. Carbon, nitrogen, and phosphorus dynamics in a loblolly pine-goat silvopasture system in the Southeast USA. Agrof Syst. 2012;86:129-40.

Ouyang S, Xiang W, Gou M, Lei P, Chen L, Deng X. Variations in soil carbon, nitrogen, phosphorus and stoichiometry along forest succession in southern China; 2018.

Padmakumar B, Sreekanth N, Shanthiprabha V, Paul J, Sreedharan K, Augustine T, Jayasooryan K, Rameshan M, Mohan M, Ramasamy EV, Thomas AP. Tree 
biomass and carbon density estimation in the tropical dry forest of Southern Western Ghats, India; 2018.

Pan Y, Birdsey RA, Fang J, Houghton R, Kauppi PE, Kurz WA, Phillips OL, Shvidenko A, Lewis SL, Canadell JG. A large and persistent carbon sink in the world's forests. Science. 2011. https://doi.org/10.1126/science.1201609.

Pearson TR, Brown SL, Birdsey RA. Measurement guidelines for the sequestration of forest carbon. In: Gen. Tech. Rep. NRS-18. Newtown Square: US Department of Agriculture, Forest Service, Northern Research Station; 2007. p. 27-9.

$R$ Core Team. R: a language and environment for statistical computing. Vienna: $R$ Foundation for Statistical Computing; 2016. https://www.r-project.org/

Réjou-Méchain M, Tanguy A, Piponiot C, Chave J, Hérault B. Biomass: an r package for estimating above-ground biomass and its uncertainty in tropical forests. Methods Ecol Evol. 2017:8:1163-7.

Rubin BD, Manion PD, Faber-Langendoen D. Diameter distributions and structural sustainability in forests. Forest Ecol Manag. 2006;222:427-38.

Sagar R, Raghubanshi A, Singh J. Tree species composition, dispersion and diversity along a disturbance gradient in a dry tropical forest region of India. Forest Ecol Manag. 2003;186:61-71.

Sahle M. Estimating and mapping of carbon stocks based on remote sensing, GIS and ground survey in the Menagesha Suba State Forest, Ethiopia. M. Sc. Thesis. Addis Ababa: University School of Graduate Studies College of Natural Sciences School of Earth and Planetary Science Department of Earth Science; 2011.

Selmants PC, Litton CM, Giardina CP, Asner GP. Ecosystem carbon storage does not vary with mean annual temperature in Hawaiian tropical montane wet forests. Glob Chang Biol. 2014;20:2927-37.

Sharma CM, Baduni NP, Gairola S, Ghildiyal SK, Suyal S. Tree diversity and carbon stocks of some major forest types of Garhwal Himalaya, India. Forest Ecol Manag. 2010:260:2170-9.

Sierra CA, del Valle Jl, Orrego SA, Moreno FH, Harmon ME, Zapata M, Colorado GJ, Herrera MA, Lara W, Restrepo DE. Total carbon stocks in a tropical forest landscape of the Porce Region, Colombia. Forest Ecol Manag. 2007;243:299-309.

Simegn TY, Soromessa T. Carbon stock variations along altitudinal and slope gradient in the forest belt of Simen Mountains National Park, Ethiopia. Am J Environ Prot. 2015:4:199-201.

Simon A, Dhendup K, Rai P, Gratzer G. Soil carbon stocks along elevational gradients in Eastern Himalayan mountain forests. Geoderma Reg. 2018;12:28-38.

Spracklen D, Righelato R. Tropical montane forests are a larger than expected global carbon store. Biogeosciences. 2014;11:2741-54.

Srinivas K, Sundarapandian S. Biomass and carbon stocks of trees in the tropical dry forest of East Godavari region, Andhra Pradesh, India. Geology Ecol Landsc. 2018:1-9. https://doi.org/10.1080/24749508.2018.1522837.

Tadesse T. The value of some forest ecosystem services in Ethiopia. In: Proceeding of a workshop on Ethiopian forestry at crossroads: the need for a strong institution. Forum for environment. Addis Ababa: Ethiopia Google Scholar; 2008. p. 83-98.

Tanner LH, Wilckens MT, Nivison MA, Johnson KM. Biomass and soil carbon stocks in the wet montane forest, Monteverde region, Costa Rica: assessments and challenges for quantifying accumulation rates. Int J For Res. 2016. Article ID 5812043, p. 8.

Teketay D, Lemenih M, Bekele T, Yemshaw Y, Feleke S, Tadesse W, Moges Y, Hunde T, Nigussie D. Forest resources and challenges of sustainable forest management and conservation in Ethiopia. In: Degraded forests in Eastern Africa: management and restoration; 2010. p. 19-63.

UNFCCC, COP. Outcome of the work of the ad hoc working group on long--term cooperative action under the convention. Decision. 2010.

Unger M, Leuschner C, Homeier J. Variability of indices of macronutrient availability in soils at different spatial scales along an elevation transect in tropical moist forests (NE Ecuador). Plant Soil. 2010;336:443-58.

Valencia R, Condit R, Muller-Landau HC, Hernandez C, Navarrete H. Dissecting biomass dynamics in a large Amazonian forest plot. J Tropical Ecol. 2009;25:473-82.

Vilanova E, Ramírez-Angulo H, Torres-Lezama A, Aymard G, Gámez L, Durán C, Hernández L, Herrera R, van der Heijden G, Phillips OL. Environmental drivers of forest structure and stem turnover across Venezuelan tropical forests. PloS One. 2018;13:e0198489.

Walkley A, Black IA. An examination of the Degtjareff method for determining soil organic matter, and a proposed modification of the chromic acid titration method. Soil Sci. 1934;37:29-38.
Wassie A, Teketay D, Powell N. Church forests provide clues to restoring ecosystems in the degraded highlands of northern Ethiopia. Ecol Rest. 2005;23:131-2

Willcock S, Phillips OL, Platts PJ, Balmford A, Burgess ND, Lovett JC, Ahrends A, Bayliss J, Doggart N, Doody K. Quantifying and understanding carbon storage and sequestration within the Eastern Arc Mountains of Tanzania, a tropical biodiversity hotspot. Carbon Balance Manag. 2014;9:2.

Winfree RW, Fox J, Williams NM, Reilly JR, Cariveau DP. Abundance of common species, not species richness, drives delivery of a real-world ecosystem service. Ecology letters. 2015;18: 626-635.

Yachi S, Loreau M. Does complementary resource use enhance ecosystem functioning? A model of light competition in plant communities. Ecol Lett. 2007;10:54-62.

Yohannes H, Soromessa T, Argaw M. Carbon stock analysis along with an altitudinal gradient in Gedo Forest: implications for forest management and climate change mitigation. Am J Environ Prot. 2015;4:237-44.

Zanne A, Lopez-Gonzalez G, Coomes D, llic J, Jansen S, Lewis S, Miller R, Swenson N, Wiemann M, Chave J. Global wood density database: Dryad; 2009. Identifier: http://hdl.handle.net/10255/dryad.235

\section{Ready to submit your research? Choose BMC and benefit from:}

- fast, convenient online submission

- thorough peer review by experienced researchers in your field

- rapid publication on acceptance

- support for research data, including large and complex data types

- gold Open Access which fosters wider collaboration and increased citations

- maximum visibility for your research: over $100 \mathrm{M}$ website views per year

At BMC, research is always in progress.

Learn more biomedcentral.com/submissions 